\title{
Size-specific PAHs and Associated Health Risks over a Tropical Urban Metropolis: Role of Long-range Transport and Meteorology
}

\author{
Debajyoti Ray $^{1 *}$, Abhinandan Ghosh ${ }^{1}$, Abhijit Chatterjee ${ }^{1,2 *}$, Sanjay K. Ghosh ${ }^{1,2,3}$, \\ Sibaji Raha ${ }^{2,3}$ \\ ${ }^{1}$ Environmental Sciences Section, Bose Institute, Kolkata 700054, India \\ ${ }^{2}$ Centre for Astroparticle Physics and Space Science, Kolkata-700091, India \\ ${ }^{3}$ Department of Physics, Bose Institute, Kolkata-700009, India
}

\begin{abstract}
The polycyclic aromatic hydrocarbons (PAHs) are considered as an important class of organic pollutants in the urban atmosphere to pose serious health hazards. A comprehensive study was conducted during the dry seasons of 2017-2018 to understand the impacts of local sources, meteorology, boundary layer dynamics, and long-range transport, on the sizespecific particulate PAHs (Coarse: 10-2.1 $\mu \mathrm{m}$; Superfine: $2.1-1.1 \mu \mathrm{m}$; Accumulation: $1.1-0.4 \mu \mathrm{m}$ and Ultrafine: $<0.4 \mu \mathrm{m}$ ). Samples were collected over Kolkata $\left(22.33^{\circ} \mathrm{N}\right.$ and $\left.88.20^{\circ} \mathrm{E}\right)$, a megacity of the lower Indo-Gangetic Plain (IGP). Wintertime distributions of all PAHs were exclusively unimodal with their maximum abundance in accumulation mode, whereas the 4,5 and 6-ring PAHs showed additional coarse mode peaks during post-monsoon and pre-monsoon. The Concentration Weighted Trajectory model has identified the middle IGP and the Eastern Ghats as the potent PAH source regions for the receptor site. Meteorology significantly influenced, in minimizing the contributions of transported PAHs from biomass burning regions of Eastern Ghats during pre-monsoon. On the contrary, meteorology favored the PAHs accumulation from local emissions and long-range transport during winter and post-monsoon. Source apportionment by positive matrix factorization model identified unburned petroleum, incineration, fossil fuel and coal burning as possible major sources of size-specific PAHs. Additionally, based on benzo(a)pyrene equivalent concentrations, the incremental lifetime cancer risk (ILCR) values were estimated for four human age groups. In general, ILCR values were influenced by the accumulation mode, and they were highest for all size ranges during winter. The estimated upper limit of ILCR $\left(9.26 \times 10^{-6}\right)$ exceeding the carcinogenic benchmark level $\left(1 \times 10^{-6}\right)$, draws attention towards the adverse impacts of wintertime ultrafine PAHs on human health in Kolkata, where poor air quality is already a major concern.
\end{abstract}

Keywords: Size-specific particulate PAH; Seasonal distribution pattern; Long-range transport; Source apportionment; Incremental lifetime cancer risk.

\section{INTRODUCTION}

Polycyclic aromatic hydrocarbons (PAH) are unpreventable byproducts of fuel, garbage and biomass combustion. They are one of the most prominent organic pollutants in the atmosphere with adverse effects on human health and have been ranked within the top ten positions out of 275 hazardous chemicals in the priority list of hazardous substances by the Agency for Toxic Substances and Diseases Registry (ATSDR

\footnotetext{
* Corresponding author.

Tel.: +919051585800

E-mail address: abhijit.boseinst@gmail.com

** Corresponding author.

Tel.: +918017895824

E-mail address: debajyoti.ray@jcbose.ac.in
}

2017 Substance Priority List) (https://www.atsdr.cdc.gov/S PL/index.html, accessed on 08-05-2019). In addition to molecular weight (i.e., lighter or heavier), the health-damaging potential of the PAHs can also be classified based on their accumulation and abundances in different aerosol sizes. In fact, the efficiency of the PAHs in reaching to the tracheobronchial or alveolar region of the human respiratory tract and even to the bloodstream (Kajiwara et al., 2007; Monsalve et al., 2013; Velali et al., 2016) enhances as the substrate aerosol size decreases. The population-based cohort studies using a quantitative assessment of $\mathrm{PAH}$ exposure revealed intrauterine growth restriction inducing low birth weight (Choi et al., 2012; Polanska et al., 2014), fatal ischemic heart disease (Burstyn et al., 2005), enhanced risk of asthma in children (Al-Daghri et al., 2013; Karimi et al., 2015) and cancer in humans (Boada et al., 2015).

Gas-particle partitioning governs the atmospheric lifetimes of the PAHs in local, regional and global perspectives by 
influencing their distribution, transport, and degradation (Terzi and Samara, 2004; Lammel et al., 2009; Friedman and Selin, 2012). The micrometeorological parameters (such as temperature, relative humidity, solar radiation and wind speed), aerodynamic diameter $\left(D_{\mathrm{p}}\right)$ of particulate matter (PM) and physicochemical properties (such as vapor pressure) substantially influence the gas-particle partitioning of various atmospheric organic pollutants (Shimmo et al., 2004; Xu et al., 2017; Zhu et al., 2017; Barbas et al., 2018).

The information on the size-specific abundances of PAHs over the urban atmosphere at Indo-Gangetic Plain has not been available to date to the best of our knowledge. Therefore, data of the size-specific distribution of PAHs in a densely populated urban atmosphere is crucial (Poschl and Shiraiwa, 2015 ) as their potential to damage human health depends on their accumulation in different aerosol sizes. Size-specific distribution of PAHs is also crucial to understand their heterogeneous (photo)chemical aging as well as to identify their sources (Lv et al., 2016).

The present study was focused on the temporal variations of size-specific PAHs and their possible health risk assessment during the dry season over Kolkata, a densely populated megacity located at the lower Indo-Gangetic Plain region at eastern India. The following questions were addressed: 1) how the micro-meteorological parameters and long-range transport relatively dominated and regulated the temporal variations of size-specific PAHs? 2) How the sources of PAHs varied with different size ranges? And, 3) what are the potentials of the PAHs towards the human health risk in terms of incremental lifetime cancer risk?

\section{EXPERIMENTAL METHODS}

\section{Sampling Site and Synoptic Meteorology}

Figs. 1(a) and 1(b) shows the geographical location of the sampling site in Kolkata $\left(22^{\circ} 33^{\prime} \mathrm{N}\right.$ and $88^{\circ} 20^{\prime} \mathrm{E}$, the average elevation of $6.4 \mathrm{~m}$ amsl), which is located along the east bank of the Hooghly River in the lower region of the IndoGangetic plain. The sampling site is on the campus of Bose Institute that is situated at the eastern edge of the city and in the center of the Kolkata metropolitan area. The site can be described as a commercial cum residential area and major roads with a distance of 100 meters surround it. More details of the sampling site are given in our recent publications (Ray et al., 2017; Ghosh et al., 2019).

Table 1 summarizes the range and average values of mixing layer depth as well as micrometeorological parameters such as temperature, relative humidity, solar radiation, and wind speed over Kolkata during the study period. In general, all the meteorological parameters (except relative humidity) showed maximum recorded values during pre-monsoon, which were significantly higher than the other seasons. The ambient temperature and wind speed followed the order: pre-monsoon $>$ post-monsoon $>$ winter. On the other hand, solar radiation and the mixed layer depth followed the order: pre-monsoon $>$ winter $>$ post-monsoon. The surface-reaching solar radiation during pre-monsoon was more than doubled compared to post-monsoon. The mixed layer depths during winter and post-monsoon were comparable but much lower than premonsoon when the average value exceeded $1000 \mathrm{~m}$. The average relative humidity was $>70 \%$ during the study period, however, the winter season was observed to be least humid.
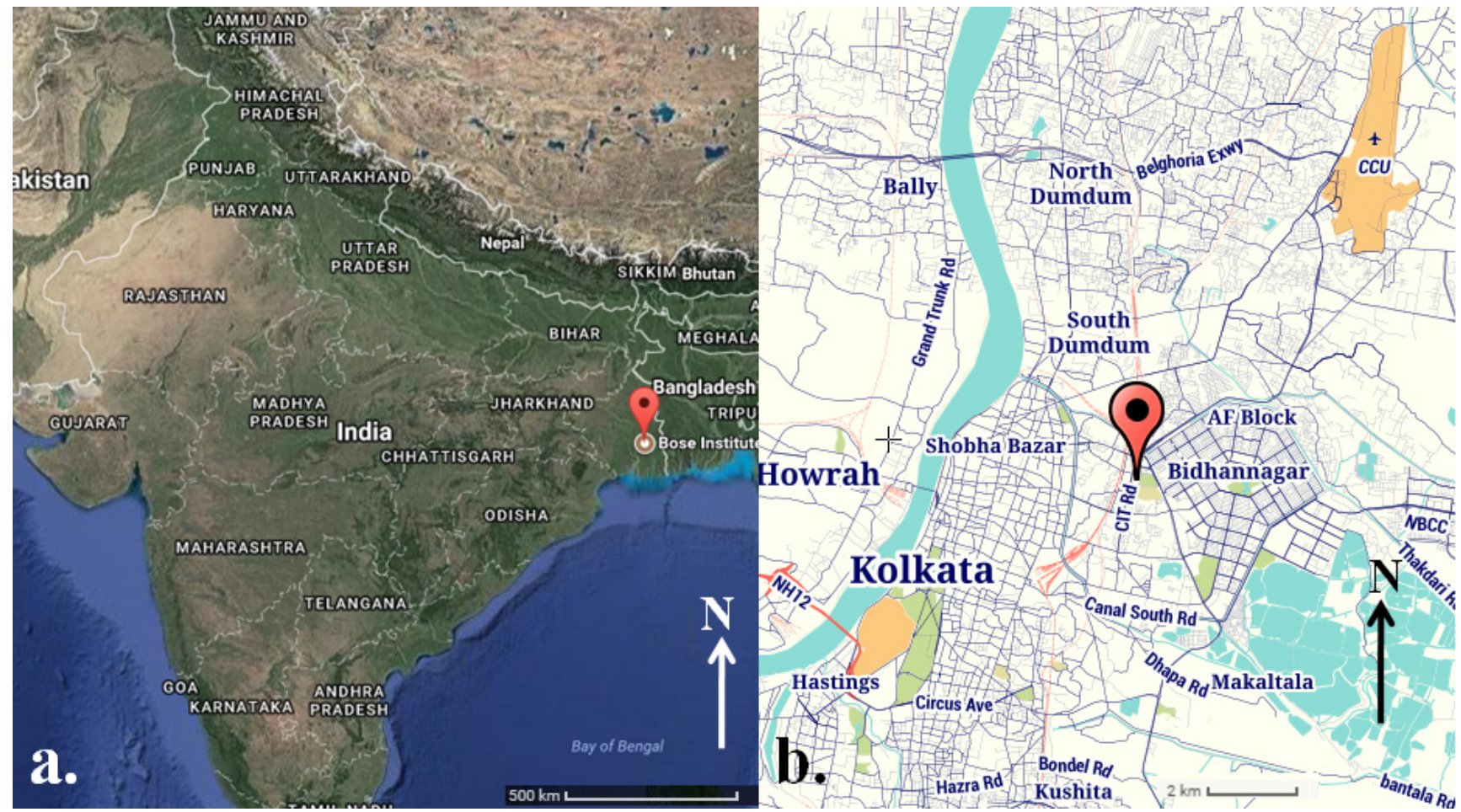

Fig. 1. (a) Geographical location of Kolkata in India (red balloon). (b) The sampling site in Kolkata as indicated with red balloon. 
Table 1. Mean seasonal concentrations with standard deviations and seasonal ranges of mixing layer depth and micrometeorological parameters over Kolkata during the study period.

\begin{tabular}{llllll}
\hline Season & ${ }^{\mathrm{a}} \mathrm{T} /{ }^{\circ} \mathrm{C}$ & $\mathrm{RH} / \%$ & $\mathrm{SR} / \mathrm{W} \mathrm{m}{ }^{-2}$ & $\mathrm{WS} / \mathrm{m} \mathrm{s}^{-1}$ & $\mathrm{MLD} / \mathrm{m}$ \\
\hline post-monsoon & $29.2 \pm 2.9$ & $77.8 \pm 6.2$ & $163.1 \pm 10.1$ & $1.5 \pm 0.25$ & $771.4 \pm 82.8$ \\
& $26.1-33.1$ & $68.2-86.5$ & $150.7-177.2$ & $1.0-1.9$ & $945.5-706.5$ \\
Winter & $24.8 \pm 3.2$ & $70.9 \pm 11.9$ & $236.8 \pm 17.1$ & $1.2 \pm 0.4$ & $685.7 \pm 33.6$ \\
& $20.4-28.6$ & $55.7-86.2$ & $214.8-258.6$ & $0.7-2.1$ & $733.5-642.5$ \\
pre-monsoon & $32.1 \pm 2.4$ & $74.7 \pm 15.8$ & $360.4 \pm 23.9$ & $2.2 \pm 0.6$ & $1004.3 \pm 20.7$ \\
& $29.4-36.7$ & $56.8-91.3$ & $328.9-386.7$ & $1.4-3.2$ & $1033.5-960.5$ \\
\hline
\end{tabular}

a Abbreviations represent: T: temperature; RH: relative humidity; SR: solar radiation; WS: wind speed; MLD: mixing layer depth.

\section{Size-specific Aerosol Collection}

Size-specific aerosol particles (PM) were collected during October 2017-May 2018, by using a 9-stage Anderson Cascade Impactor at the average flow rate of $28.3 \mathrm{~L} \mathrm{~min}^{-1}$. The inlet diameter was $10 \mu \mathrm{m}$ and cut-off points of PM aerodynamic diameters $\left(D_{\mathrm{p}}\right)$ were at 9.0, 5.8, 4.7, 3.3, 2.1, 1.1, 0.7 and $0.4 \mu \mathrm{m}$. Each stage of the impactor was equipped with a pre-baked quartz filter paper. All the filter papers were weighed before and after each sampling following a $24 \mathrm{~h}$ equilibration inside a constant temperature $\left(25^{\circ} \mathrm{C}\right)$ and humidity $(\sim 40 \%)$ chamber. The impactor was placed at the roof of the institute building at an approximate height of $15 \mathrm{~m}$ from the ground level. The instrument was operated for 72 hours continuously (12:00 IST-12:00 IST) to collect an adequate amount of sample. A total of 32 sets of samples were collected, once a week, four weeks in a month, and eight months of an entire dry season of the year. To study the seasonal variation of particulate PAHs, the sampling period was divided into three seasons, such as post-monsoon (October and November), winter (December-February) and pre-monsoon (March-May).

\section{PAH Extraction and Analysis}

The PAHs were extracted from 288 filter papers ( 9 filter papers $\times 32$ sets of samples) following the same procedure described by Ray and coworkers (Ray et al., 2017). However, the method has been briefly described in the supplementary. The extracts were analyzed with a high-performance liquid chromatography (HPLC, Shimadzu Prominence) using both UV and fluorescence detector (Shimadzu RF 10AXL). $2 \mu \mathrm{L}$ extract was injected into the system equipped with a C-18 reversed-phase chromatographic column (Supelcosil ${ }^{\mathrm{TM}} \mathrm{LC}$ PAH, $15 \mathrm{~cm} \times 4.6 \mathrm{~mm}, 5 \mu \mathrm{m})$ and the analysis was performed using a gradient composed of acetonitrile (Gradient grade LiChrosolv ${ }^{\circledR}$ Merck, India) and water (18 M $\Omega$ water) at a

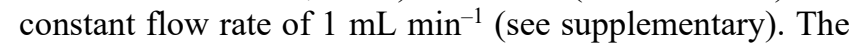
following 17 PAHs were quantified: acenaphthylene (ACY), acenaphthene (ACE), fluorene (FLU), phenanthrene (PHE), anthracene (ANT), fluoranthene (FLT), pyrene (PYR), benzo[a]anthracene (BaA), chrysene (CHRY), benzo[b]fluoranthene $(\mathrm{BbF})$, benzo[k]fluoranthene $(\mathrm{BkF})$, benzo[a]pyrene $(\mathrm{BaP}), \quad$ dibenz[a,h]anthracene (DBahA), benzo[ghi]perylene (BghiP), indeno[1,2,3-cd]pyrene (IND), 7,12-dimethylbenz(a)anthracene (DMBA) and dibenzo[a,i]pyrene (DBaiP). The accuracy of the analytical method was determined from the differences between spiked-by-surrogate compound and unspiked samples. They were analyzed in triplicate for each season. Insignificant background interference was observed from the field blanks and around 91\% recoveries were observed for solvent blanks. Therefore, corrections of PAH concentrations were performed using the recoveries $(73-110 \%)$ of the surrogate for each sample. Additionally, based on the standard deviation of the response and slope, the instrumental LODs were estimated by injecting seven replicates of $0.5 \mathrm{ppm} \mathrm{PAH}$ standard solutions (Shrivastava and Gupta, 2011). Table S2 describes the instrumental limits of detection (LODs) of the 17 quantified PAHs.

\section{Positive Matrix Factorization (PMF) Analysis}

$\mathrm{PMF}$ is a software-based multivariate factor analysis method and which is extensively used to apportion various environmental components (e.g., PAHs) source contribution (Gao et al., 2015; Liu et al., 2017). The theoretical aspects of PMF analysis have been described elsewhere (Paatero and Tapper, 1994; Callén et al., 2014). Detail description of the analysis method including the uncertainty calculation has been given in our previous publication (Ray et al., 2017). In the present study, PMF analysis was separately performed for coarse, superfine, accumulation and ultrafine modes. For each size mode, a data set of 32 samples multiplied with 13 PAHs was submitted into the EPA PMF 5.0 (Table S3-S6), supplementary). To maintain comparability, FLU, DMBaA, DBahA, and DBaiP were excluded from analysis due to their zero abundance in the coarse mode. The model was run for 3 to 7 factors with the number of base run 20, extra modeling uncertainty of $10 \%$ and random seed value. In order to reproduce results, the seed values were later fixed at 52, 72, 77 and 59 for coarse, superfine, accumulation and ultrafine PM respectively. Following Hopke (2000), five-factor models provided optimal solutions, so that the $\mathrm{Q}$ (theoretical), $\mathrm{Q}$ (robust) and $\mathrm{Q}$ (true) values were closest (Table S7-S10), supplementary) and manifested the most realistic physical scenario for all four PM size modes. The scaled residuals for $78-83 \%$ of data were within \pm 3 standard deviation. Additionally, the optimal solutions were bootstrapped 100 times with a threshold correlation R-value of 0.6 (Table S11S14), supplementary) and the effect of rotation was checked by varying the Fpeak parameters $(-0.2,-0.1,0.3,0.2,0.1)$ for all four PM size modes (Table S15-S18), supplementary). 


\section{Retrieval of MODIS Active Fire Count and HYSPLIT Air Mass Back Trajectories}

Active fire count data used in this study were taken from MODIS collection 6 data (a combined product from Terra and Aqua, MCD14ML taken from Fire Information for Resource Management System, FIRMS). A MODIS collection 6 fire products have new improved algorithms to reduce the false alarm and detecting small fires with high precision. Only those data with confidence level $\geq 80 \%$ were taken and plotted using an open-source GIS software QGIS.

In order to investigate the role of long-range transport on particulate PAH load over Kolkata, 120 hours' air mass back trajectories culminating at 00:00 UTC, 06:00 UTC, 12:00 UTC and 18:00 UTC at a height of $500 \mathrm{~m}$ above ground level has been calculated using the Hybrid Single Particle Lagrangian Integrated Trajectory (HYSPLIT) Model for all the sampling events. Trajectories were graduated according to their heights, ensemble and plotted using open source GIS software MeteoInfo (Wang, 2014).

\section{Concentration Weighted Trajectory (CWT) Model}

The relative significance of potential sources to the measured size-segregated PAH's over Kolkata was investigated by using the Concentration Weighted Trajectory (CWT) model (Wang et al., 2009). CWT is a method where species concentrations at the receptor site are assigned to the corresponding air mass back trajectories. The expected source regions are divided into an array of $i$ by $j$ grid cell. Thus, the Concentration Weighted Trajectory is defined by Eq. (1) for the $i j^{\text {th }}$ grid cell as:

$$
C_{i j}=\frac{1}{\sum_{l=1}^{M} T_{i j l}} \sum_{l=1}^{M} C_{l} T_{i j l}
$$

where $C_{i j}$ is the average weighted concentration in the $i j^{\text {th }}$ grid cell, $C_{l}$ is the species concentration at the receptor site on arrival of trajectory $l, M$ is the total number of trajectories, and $T_{i j l}$ is the total number of trajectory endpoints in the $i j^{\text {th }}$ grid cell associated with the $C_{l}$ sample. In order to eliminate the grid cells containing few trajectory endpoints, the CWT method also employs an arbitrary weight function. The CWT is a function of the PAHs concentrations at the receptor sites along with the residence times of the trajectories in each grid cells. The CWT values are represented with a color scale over the domain of the interest where red and orange signifies strong source region while green and blue represent moderate to low source region to the receptor site. Back-trajectory data for CWT analysis was taken from the Global Data Assimilation System database (GDAS1) maintained by the National Centers for Environmental Prediction (NCEP).

\section{Cloud-Aerosol LIDAR with Orthogonal Polarization (CALIOP) Observation}

The Cloud-Aerosol Lidar with Orthogonal Polarization (CALIOP) has two wavelengths polarization LIDAR which provides information about the global profiling of aerosol and cloud in the troposphere and lower-stratosphere since
May 2006 (Winker et al., 2009). It is the primary onboard instrument of the Cloud-Aerosol Lidar and Infrared Pathfinder Satellite Observations (CALIPSO) satellite. The aerosol types classified in the CALIPSO aerosol model are smoke (biomass burning), polluted dust (mixtures of dust and smoke), dust, polluted continental, clean continental, clean marine, volcanic ash, and sulfate. The vertical profile of the aerosol was obtained using CALIOP over Kolkata during different seasons.

\section{Inhalation Risk Assessment}

Based on the recommendations by the United States Environmental Protection Agency (USEPA) (EPA/600/R93/089, July 1993), the BaP toxicity equivalent concentration $\left(\mathrm{BaP}_{\mathrm{eq}}\right)$ was calculated using Eq. (2), by multiplying concentrations of each of the PAHs with their corresponding toxicity equivalent factors (TEFs). The TEF values were taken from (Chen and Liao, 2006), where TEF value for BaP was taken as 1 (Nisbet and LaGoy, 1992).

$$
\mathrm{BaP}_{\mathrm{eq}}=\sum_{i=1}^{14} c_{i}\left(\mathrm{ng} \mathrm{m}^{-3}\right) \mathrm{TEF}_{\mathrm{i}}
$$

The health risk due to exposure to the PAHs by inhalation was estimated in terms of incremental lifetime cancer risk (ILCR) model (Chen and Liao, 2006; Kaur et al., 2013; Hoseini et al., 2016) for four age groups, such as pre-school (2-5 years), school-goers (5-18 years), working (18-60 years) and retired (60-70 years) using Eq. (3).

$\mathrm{ILCR}=\mathrm{LADD} \times \mathrm{CSF} \times \sqrt[3]{(\mathrm{BW} / 70)} \times \mathrm{cf}$

where CSF is the cancer slope factor, which is an estimation of the cancer risk due to exposure to a potentially carcinogenic compound. The value of CSF was taken as $3.14\left(\mathrm{mg} \mathrm{kg}^{-1} \mathrm{day}^{-1}\right)^{-1}$ (Chen and Liao, 2006). The $\mathrm{cf}$ is a conversion factor $\left(10^{-6}\right)$ (U.S. EPA, 2011) and LADD is the lifetime average daily dose, which is defined as,

$\mathrm{LADD}=\frac{\mathrm{BaP}_{\mathrm{eq}} \times \mathrm{IR} \times \mathrm{EF} \times \mathrm{ED}}{\mathrm{BW} \times \mathrm{AT}}$

where IR is the inhalation rate $\left(\mathrm{m}^{3}\right.$ day $\left.^{-1}\right), \mathrm{EF}$ is the exposure frequency (day year ${ }^{-1}$ ), ED is the exposure duration (years), BW is the body weight ( $\mathrm{kg}), \mathrm{AT}$ is the average lifetime (days). The input parameters in Eq. (4) for the four age groups are given in Table S19.

\section{RESULTS AND DISCUSSION}

\section{Seasonal Variations and the Mass-size Distribution of PAHS}

Table 2 summarizes the seasonal mean concentrations of size-specific aerosols, total PAH (TPAH), PAHs of different ring sizes and their contributions to the TPAH during the study period. The mean $\mathrm{PM}_{10}$ concentration over Kolkata was $(174.3 \pm 88.6) \mu \mathrm{g} \mathrm{m}^{-3}$ with a range of (313.4-55.4) $\mu \mathrm{g} \mathrm{m}^{-3}$ 
Table 2. Seasonal concentrations of size-specific PM and PAHs and the percentage contributions of 3,4- and 5,6-PAHs to the total PAHs over Kolkata during the study period.

\begin{tabular}{|c|c|c|c|c|c|c|c|}
\hline \multirow{2}{*}{ seasons } & \multirow{2}{*}{ mode } & \multicolumn{4}{|c|}{ concentrations } & \multicolumn{2}{|c|}{$\%$ contributions to TPAH } \\
\hline & & $\mathrm{PM} / \mu \mathrm{g} \mathrm{m}^{-3}$ & $3,4-\mathrm{PAH} / \mathrm{ng} \mathrm{m}^{-3}$ & $5,6-\mathrm{PAH} / \mathrm{ng} \mathrm{m}^{-3}$ & $\mathrm{TPAH} / \mathrm{ng} \mathrm{m}^{-3}$ & 3,4-PAH & 5,6-PAH \\
\hline post- & ${ }^{\mathrm{a}} \mathrm{C}$ & $62.7 \pm 16.2$ & $6.8 \pm 1.3$ & $6.6 \pm 2.0$ & $13.4 \pm 1.5$ & 50.9 & 49.1 \\
\hline \multirow[t]{4}{*}{ monsoon } & $\mathrm{SF}$ & $20.7 \pm 7.4$ & $6.2 \pm 2.1$ & $3.4 \pm 0.9$ & $9.6 \pm \pm 1.9$ & 64.7 & 35.3 \\
\hline & $\mathrm{AC}$ & $68.4 \pm 35.2$ & $28.2 \pm 7.6$ & $19.7 \pm 5.2$ & $47.9 \pm 7.5$ & 58.9 & 41.1 \\
\hline & UF & $48.6 \pm 10.9$ & $9.6 \pm 1.4$ & $10.0 \pm 1.1$ & $19.6 \pm 2.8$ & 49.0 & 51.0 \\
\hline & Total & $200.4 \pm 68.6$ & $50.9 \pm 10.7$ & $39.7 \pm 7.4$ & $90.6 \pm 11.1$ & 56.2 & 43.8 \\
\hline \multirow[t]{5}{*}{ winter } & $\mathrm{C}$ & $57.8 \pm 22.5$ & $1.3 \pm 0.2$ & $1.8 \pm 0.4$ & $3.1 \pm 2.5$ & 42.6 & 57.4 \\
\hline & SF & $22.0 \pm 13.2$ & $6.7 \pm 0.9$ & $4.7 \pm 0.9$ & $11.4 \pm 3.1$ & 59.0 & 41.0 \\
\hline & $\mathrm{AC}$ & $79.1 \pm 9.8$ & $47.1 \pm 12.8$ & $35.2 \pm 5.8$ & $82.3 \pm 13.9$ & 57.2 & 42.8 \\
\hline & UF & $76.5 \pm 24.5$ & $13.0 \pm 2.6$ & $12.2 \pm 1.3$ & $25.3 \pm 3.2$ & 51.6 & 48.4 \\
\hline & Total & $235.4 \pm 56.6$ & $68.2 \pm 17.4$ & $53.9 \pm 9.7$ & $122.1 \pm 14.3$ & 55.8 & 44.2 \\
\hline & $\mathrm{C}$ & $23.7 \pm 8.5$ & $5.7 \pm 0.7$ & $7.0 \pm 1.3$ & $12.7 \pm 3.8$ & 44.7 & 55.3 \\
\hline \multirow[t]{4}{*}{ monsoon } & SF & $9.6 \pm 3.2$ & $6.9 \pm 2.5$ & $3.5 \pm 0.8$ & $10.4 \pm 1.3$ & 66.1 & 33.9 \\
\hline & $\mathrm{AC}$ & $21.1 \pm 8.1$ & $18.8 \pm 4.4$ & $17.4 \pm 4.3$ & $36.2 \pm 5.8$ & 51.9 & 48.1 \\
\hline & UF & $32.7 \pm 12.4$ & $4.7 \pm 0.8$ & $7.8 \pm 1.2$ & $12.6 \pm 2.6$ & 37.8 & 62.2 \\
\hline & Total & $87.1 \pm 26.7$ & $36.1 \pm 9.1$ & $35.8 \pm 7.6$ & $71.9 \pm 11.9$ & 50.2 & 49.8 \\
\hline
\end{tabular}

Abbreviations: ${ }^{\mathrm{a}} \mathrm{C}$ : coarse; SF: superfine; AC: accumulation; UF: ultrafine.

whereas the mean TPAH was $(94.9 \pm 23.7) \mathrm{ng} \mathrm{m}^{-3}$ with a range of (141.9-56.2) $\mathrm{ng} \mathrm{m}^{-3}$ during the entire study period. The highest abundances of both PM and PAHs were observed during winter followed by post-monsoon and lowest during pre-monsoon. We have split the aerosols and intrinsic PAHs into four size modes based on aerosol aerodynamic diameter $\left(D_{\mathrm{p}}\right)$ : coarse $\left(2.1 \mu \mathrm{m}<D_{\mathrm{p}}<10 \mu \mathrm{m}\right)$, superfine $\left(1.1 \mu \mathrm{m}<D_{\mathrm{p}}<\right.$ $2.1 \mu \mathrm{m})$, accumulation $\left(0.4 \mu \mathrm{m}<D_{\mathrm{p}}<1.1 \mu \mathrm{m}\right)$ and, ultrafine $\left(D_{\mathrm{p}}<0.4 \mu \mathrm{m}\right)$ mode. Aerosols in all size modes were several times higher during post-monsoon and winter in comparison to pre-monsoon. On the other hand, the wintertime size distribution of TPAHs was distinctly different from the other seasons. The coarse mode TPAH showed minimum loading in winter whereas accumulation and ultrafine mode TPAH were maximum. Moreover, except the ultrafine mode, the 3,4-ring PAHs (ACY, ACE, FLU, PHE, ANT, FLT, PYR, $\mathrm{BaA}$ and $\mathrm{CHRY}$ ) were more abundant than 5,6-ring PAHs (BbF, BkF, BaP, BghiP, IP, DMBaA, DBahA and DBaiP) in coarse, superfine and accumulation mode during the entire study period. However, the mean concentrations of 3,4- and 5,6-PAHs were $(51.7 \pm 16.4) \mathrm{ng} \mathrm{m}^{-3}$ and $(43.1 \pm 9.3) \mathrm{ng} \mathrm{m}^{-3}$ ranging between (80.8-25.9) $\mathrm{ng} \mathrm{m}^{-3}$ and (61.5-29.1) $\mathrm{ng} \mathrm{m}^{-3}$ respectively. While the 3,4 and 5,6-PAHs showed almost equal loadings in pre-monsoon, relatively colder seasons exhibited higher loading of lighter PAHs in the ambient air of Kolkata.

The seasonal size distribution of fourteen PAHs (the figures of DMBaA, DBahA, and DBaiP are not shown as they were found only in the ultrafine mode during winter), 3,4-PAHs, 5,6-PAHs, and TPAHs are described in Fig. 2. Distinct unimodal distribution was observed for all the PAHs during winter and the mode peak resides exclusively in the accumulation zone $\left(0.4 \mu \mathrm{m}<D_{\mathrm{p}}<1.1 \mu \mathrm{m}\right)$. On the other hand, PAHs showed roughly similar distribution patterns during the post- and pre-monsoon. Relatively nonvolatile 5,6-PAHs were distributed into accumulation and coarse fractions, thereby showing bimodal distributions during the post- and pre-monsoon, however, the intensities of the accumulation mode peaks were larger than the coarse mode. Most of the 3,4-ring PAHs, on the other hand, showed the highest peak in the accumulation mode during both post- and pre-monsoon, followed by a roughly steady decrease with increasing particle size. Again, the mode peak intensities were lower than winter describing the shifting of 3,4-PAHs distribution towards larger particle modes during the postmonsoon and pre-monsoon.

This observation is in quantitative agreement with earlier studies of PAHs bound to size-segregated PM (Venkataraman and Friedlander, 1994; Allen et al., 1996; Venkataraman et al.,1999; Lv et al., 2016) and can be attributed to increased volatilization of relatively more volatile 3,4-PAHs from smaller PM due to vapor pressure enhancement (Kelvin effect) followed by absorption into the existing organic fraction of larger PM (Venkataraman et al., 1999). However, this mechanism may not be solely influencing the size-segregated PAH distribution in the current study. Since atmosphere is a complex system and aerosol, as well as intrinsic pollutant distribution undoubtedly varies with source and ambient micrometeorology (Jiang and Bai, 2018), therefore possibly other mechanisms are also influencing. In fact, satellite data indicate a significant contribution of transported aerosol, mainly biomass burning (BB) aerosol from the western IGP during post-monsoon and winter whereas marine aerosol mixed with BB plumes from Eastern Ghats region during pre-monsoon (vide infra). Therefore, finer particles might have grown in size during long-range transport leading to changes in their chemical compositions and size distributions. Indeed, contrary to Allen and coworkers, lack of any particular trend in the plot of PAH mass fraction in coarse mode versus their molecular weight (Fig. S1) is suggestive of some influence of particle growth mechanism existing in the present study (Allen et al., 1996). We had compared the PAHs bound to composite aerosols over Kolkata with other atmospheric environments in India in our earlier study (Ray et al., 2017). 


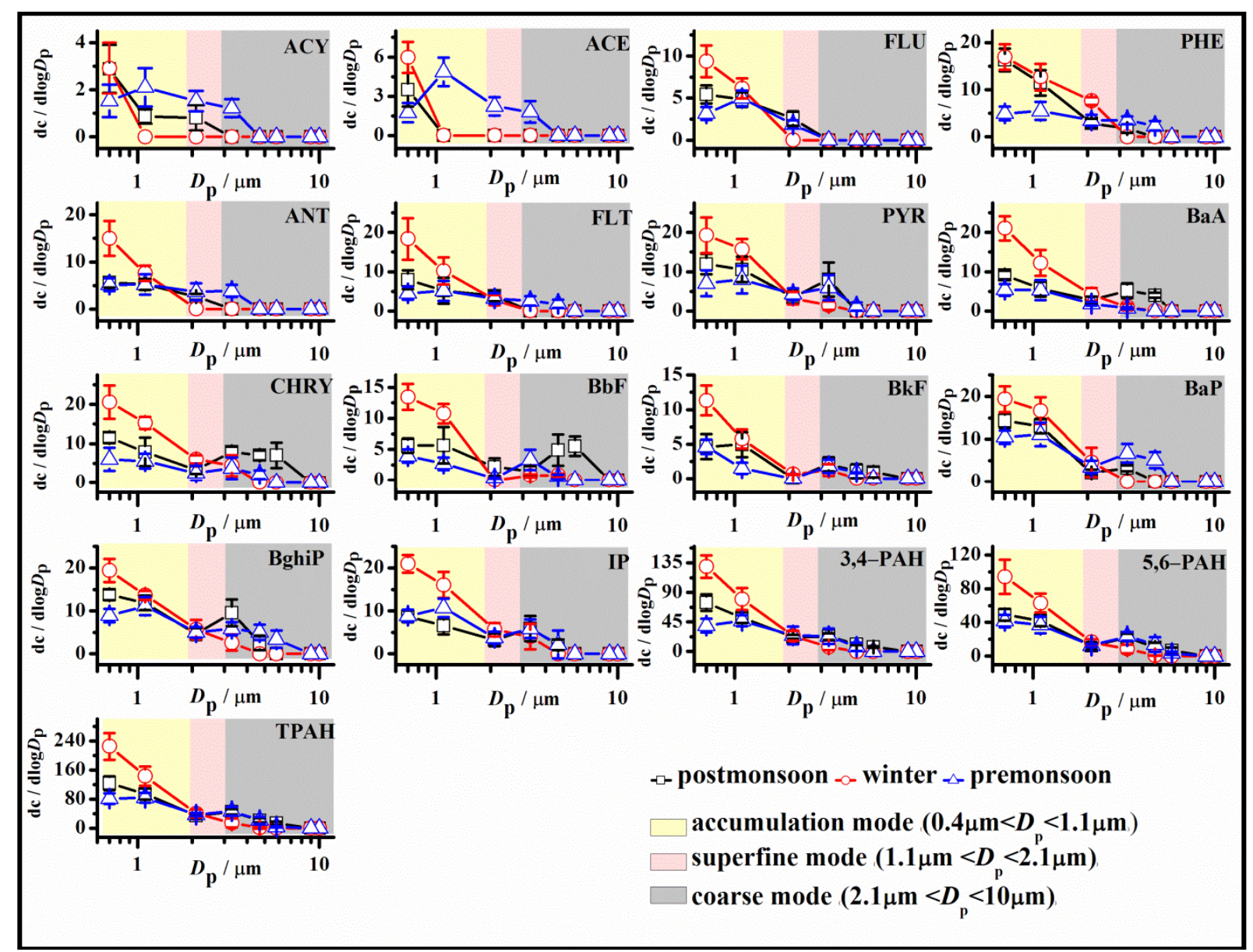

Fig. 2. Seasonal particle size-specific distributions of PAHs over Kolkata. Error bars represent standard deviations.

\section{Comparative Study}

Table 3 compares the average particulate TPAH concentration over Kolkata with other urban atmospheres across the world. In case of the present study location, Kolkata, no significant changes in TPAH concentrations have been observed from 2011 (Saha et al., 2017) to 2018 (present study). This indicates that either the sources of PAH or the other regulating factors remained more or less same during the period. Comparing the TPAH $\left(\mathrm{PM}_{10}\right)$ concentrations over Kolkata with the same over other Asian urban atmospheres, Tokyo has been found to be the cleanest city in terms of the PAH pollution where TPAH $\left(\mathrm{PM}_{10}\right)$ levels are $\sim 30$ times less than Kolkata. This is followed by Kuala Lampur and Hanoi with $\sim 3$ times and $\sim 1.5$ times less PAH levels compared to Kolkata. The TPAH $\left(\mathrm{PM}_{10}\right)$ levels at Urumqi in China have been found to be comparable or slightly higher than Kolkata. Urumqi is the largest city in Central Asia in terms of population and in the top ten cities in the world with the most air pollution according to the report published by the Asian Development Bank published in 2013. Comparing TPAH $\left(\mathrm{PM}_{10}\right)$ over Kolkata with TPAH $\left(\mathrm{PM}_{2.5}\right)$ over other Asian urban atmospheres, we observed that Tangling city in China has almost equal PAH concentrations but surprisingly, $\sim 3$ times less PAH levels have been reported for Beijing city in China. The TPAH $\left(\mathrm{PM}_{10}\right)$ values over Kolkata are 3 times lower than Delhi and $\sim 2$ times lower than Mahendragarh, an urban atmosphere in the National Capital Region (NCR) in the upper Indo-Gangetic Plain. Several factors could be involved for such a difference; however, one of such factors could be attributed to the close proximity to the area prone to crop-residue/stubble burning during pre-monsoon. If we compare TPAH $\left(\mathrm{PM}_{10}\right)$ over Kolkata with TPAH (TSP: Total Suspended Particulates) over Alexandria city in Egypt, we observed that this Egyptian city has $\sim 5$ times higher PAH pollution than Kolkata and several times higher than all the urban atmospheres across the world under comparison. The reason could be huge PAH emissions over Alexandria being an important industrial center in the world and the major center of the international shipping industry. On the contrary, the Kathmandu city in Nepal shows very low PAH pollution as compared to Kolkata in spite of being influenced by the polluted IndoGangetic Plain and its own industrial emissions. Rest of the cities (given in Table 3) show comparatively cleaner air quality than Kolkata in terms of PAH pollution. Kolkata has already been listed as one of the non-attainment cities (not meeting the National Ambient Air Quality Standard in India and World Health Organization) in India in terms of aerosol pollution. Moreover, the worse PAH levels comparative to several urban atmospheres across the world as revealed from the present study should draw the attention of the policymakers for immediate actions. 
Table 3. Comparison of the concentrations of mean TPAHs $\left(\mathrm{ng} \mathrm{m}^{-3}\right)$ from this study with the studies at different locations in the world.

\begin{tabular}{|c|c|c|c|c|c|}
\hline Location & Study Period & Size & $\begin{array}{l}\text { Number } \\
\text { of PAHs }\end{array}$ & $\begin{array}{l}\text { Mean TPAHs } \\
\left(\mathrm{ng} \mathrm{m}^{-3}\right)\end{array}$ & Reference \\
\hline Hsinchu, Taiwan & $09 / 2014-08 / 2015$ & $\mathrm{PM}_{2.5}$ & 20 & 1.6 & 1 \\
\hline Hefei City, China & $05 / 2014$ and $01 / 2015$ & $\mathrm{PM}_{2.5}$ & 16 & 21.3 & 2 \\
\hline Tokyo, Japan & $01 / 2010-12 / 2010$ & $\mathrm{PM}_{10}$ & 12 & 3.3 & 3 \\
\hline Kolkata, India & 2009-2011 & $\mathrm{PM}_{10}$ & 12 & 114 & 3 \\
\hline Hanoi, Vietnam & $10 / 2009-09 / 2010$ & $\mathrm{PM}_{10}$ & 12 & 58.8 & 3 \\
\hline Kuala Lampur, Malaysia & $09 / 2010-12 / 2011$ & $\mathrm{PM}_{10}$ & 12 & 29.4 & 3 \\
\hline Xiamen, China & $01 / 2013$ and $07 / 2013$ & $\mathrm{PM}_{2.5}$ & 17 & 10.5 & 4 \\
\hline Urumqi, China & $11 / 2015-03 / 2016$ and $07 / 2016-09 / 2016$ & $\mathrm{PM}_{10}$ & 16 & 116.4 & 5 \\
\hline Alexandria City, Egypt & $01 / 2015-02 / 2016$ & TSP & 16 & 502.4 & 6 \\
\hline Kathmandu, Nepal & $10 / 2014-08 / 2015$ & TSP & 15 & 2.8 & 7 \\
\hline Jinan, China & $03 / 2016-12 / 2016$ & $\mathrm{PM}_{2.5}$ & 18 & 33.0 & 8 \\
\hline Tehran, Iran & $05 / 2012-05 / 2013$ & $\mathrm{PM}_{2.5}$ & 16 & 12.2 & 9 \\
\hline Kigali, Rwanda & Wet and dry seasons, 2017 & $\mathrm{PM}_{2.5}$ & 15 & 36.0 & 10 \\
\hline Tongling, China & $08 / 2014-01 / 2015$ & $\mathrm{PM}_{2.5}$ & 16 & 98.0 & 11 \\
\hline Beijing, China & 07/2014-08/2014; 11/2014 & $\mathrm{PM}_{2.5}$ & 16 & 31.5 & 12 \\
\hline Delhi, India & $01 / 2016-06 / 2016$ & $\mathrm{PM}_{2.5}$ & 16 & 287.9 & 13 \\
\hline Mahendragarh, India & $01 / 2016-06 / 2016$ & $\mathrm{PM}_{2.5}$ & 16 & 158.8 & 13 \\
\hline Kolkata, India & $10 / 2017-05 / 2018$ & $\mathrm{PM}_{10}$ & 17 & 94.9 & This Study \\
\hline
\end{tabular}

References: ${ }^{1}$ Yang et al., 2017, ${ }^{2} \mathrm{Hu}$ et al., 2017, ${ }^{3}$ Saha et al., 2017, ${ }^{4}$ Zhang et al., 2018b, ${ }^{5}$ Simayi et al., $2018,{ }^{6} \mathrm{Haiba}$ et al., 2018, ${ }^{7}$ Sugiyama et al., 2017, ${ }^{8}$ Zhang et al., 2019, ${ }^{9}$ Taghvaee et al., 2018, ${ }^{10}$ Kalisa et al., 2018, ${ }^{11}$ Zhang et al., $2018 \mathrm{a}$, ${ }^{12}$ Zhang et al., 2017, ${ }^{13}$ Shivani et al., 2018.

\section{Role of Meteorology and Long-range Transport}

We showed earlier that atmospheric particulate PAH load over Kolkata is mainly influenced by the boundary layer dynamics as well as ambient meteorology (Ray et al., 2017). Also, the seasonal variation of particulate PAHs should be unaffected by local anthropogenic emissions (such as vehicular emission, municipal solid waste incineration, and others) as their contributions remain almost the same throughout the year in a megacity like Kolkata. Thus, the seasonal variations of PAHs could be explained in terms of long-range transport as well as the meteorological variations and boundary layer dynamics.

Earlier studies showed significant input of transported aerosols into the ambient air of Kolkata (Chatterjee et al., 2012; Ghosh et al., 2019). We have identified the IGP and east coast of India as the potent source region of 5,6-PAHs for the receptor site Kolkata by using the Concentration Weighted Trajectory (CWT) model. In fact, the IGP and local regions are the major source spots of accumulation and ultrafine PAHs, whereas the east coast region was found to be the dominant source spot of coarse PAHs (Fig. 3). Moreover, Figs. 4(a)-4(c) illustrates the fire activities in India during the study period. The densely accumulated fire spots during post-monsoon at the western IGP and northwestern parts of India (Fig. 4(a)) could be associated with the crop residue burning, which is a common practice over the regions during post-monsoon (Jain et al., 2014). A good number of fire spots were also observed during winter over the same regions (Fig. 4(b)), though smaller in number compared to post-monsoon. A significant number of air mass trajectories were found to arrive at Kolkata from North-West India during winter and post-monsoon (Figs. 4(d) and 4(e)).
Therefore, in addition to the favorable meteorological conditions for aerosol accumulation near the surface, such long-range transports could additionally enhance the aerosol and PAH loadings during the relatively colder seasons, such as post-monsoon and winter. On the other hand, BB is very frequent due to shifting cultivation in the Eastern Ghats regions during pre-monsoon (Vadrevu et al., 2015). Indeed, densely populated fire spots were observed along and across the entire Eastern Ghats and adjacent regions along with the north-western parts of India during pre-monsoon (Fig. 4(c)). Recently, we have reported the transport of BB plumes from the Eastern Ghats regions affecting the air quality over Kolkata metropolis and the high increase in anthropogenic water-soluble ionic components of aerosols over Kolkata during pre-monsoon (Ghosh et al., 2019). Impacts of fire smoke plumes on regional air and related deteriorations of public health quality have been reported by several research groups in other places (Dennekamp and Abramson, 2011; Haikerwal et al., 2015; Larsen et al., 2017). Fig. 4(f) shows that during pre-monsoon, the air masses originating from the Bay of Bengal cross the fire active regions at the Eastern Ghats before arriving at Kolkata. Most of these air masses maintained the altitude below $500 \mathrm{~m}$ above ground level throughout their transport when they might collect the BB aerosols and PAHs. During pre-monsoon, some of the trajectories were also observed to arrive from arid and semiarid regions of central and western India and could have brought dust particles. Few air masses also arrived from the fire active regions of northwestern India. The vertical profiling of aerosols from CALIPSO observations shows the presence of elevated layers of smoke over Kolkata during winter and post-monsoon associated with transported BB 


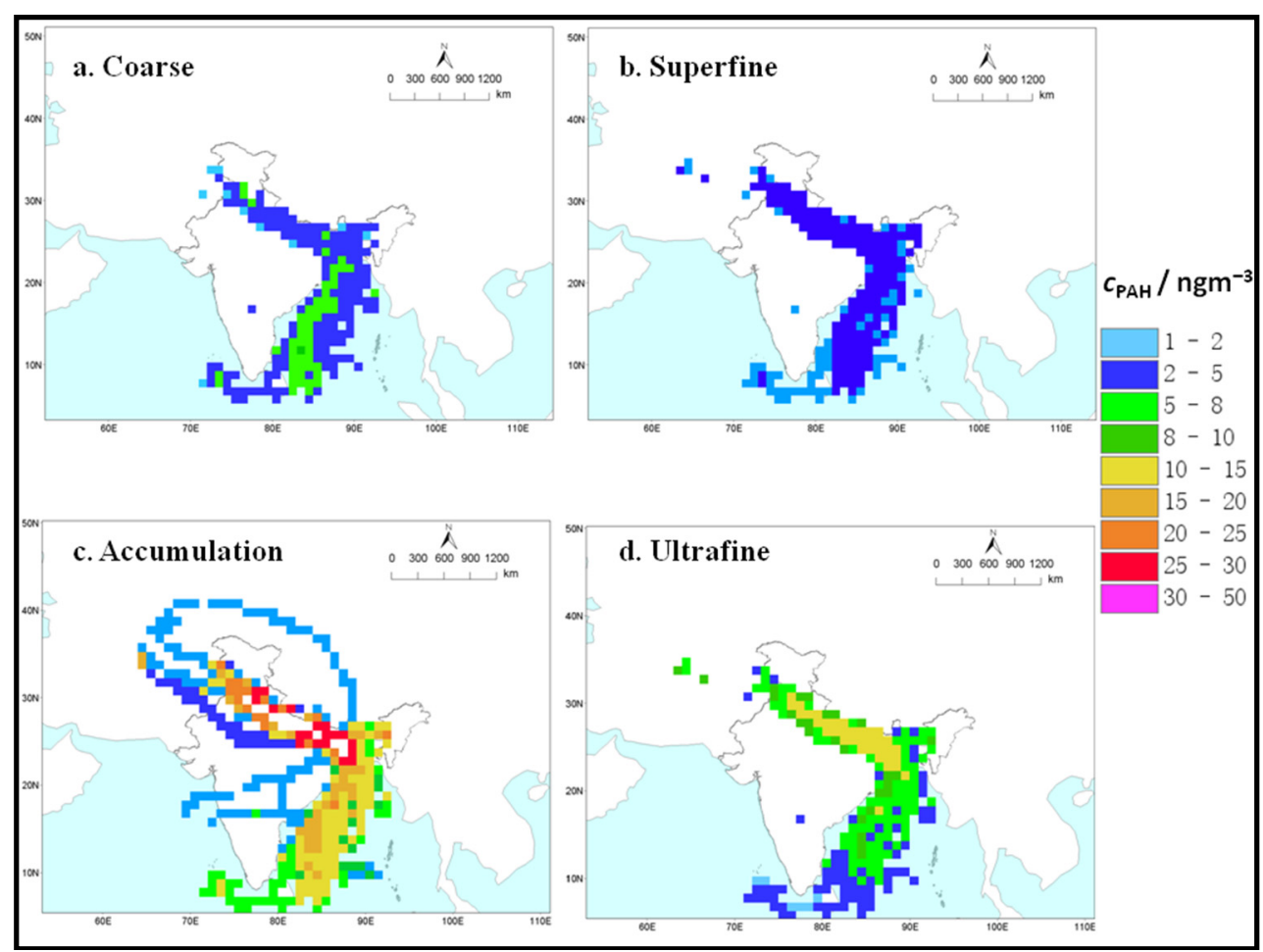

Fig. 3. Weighted concentration weight trajectory of the 5,6-PAH at the receptor site Kolkata during the study period.

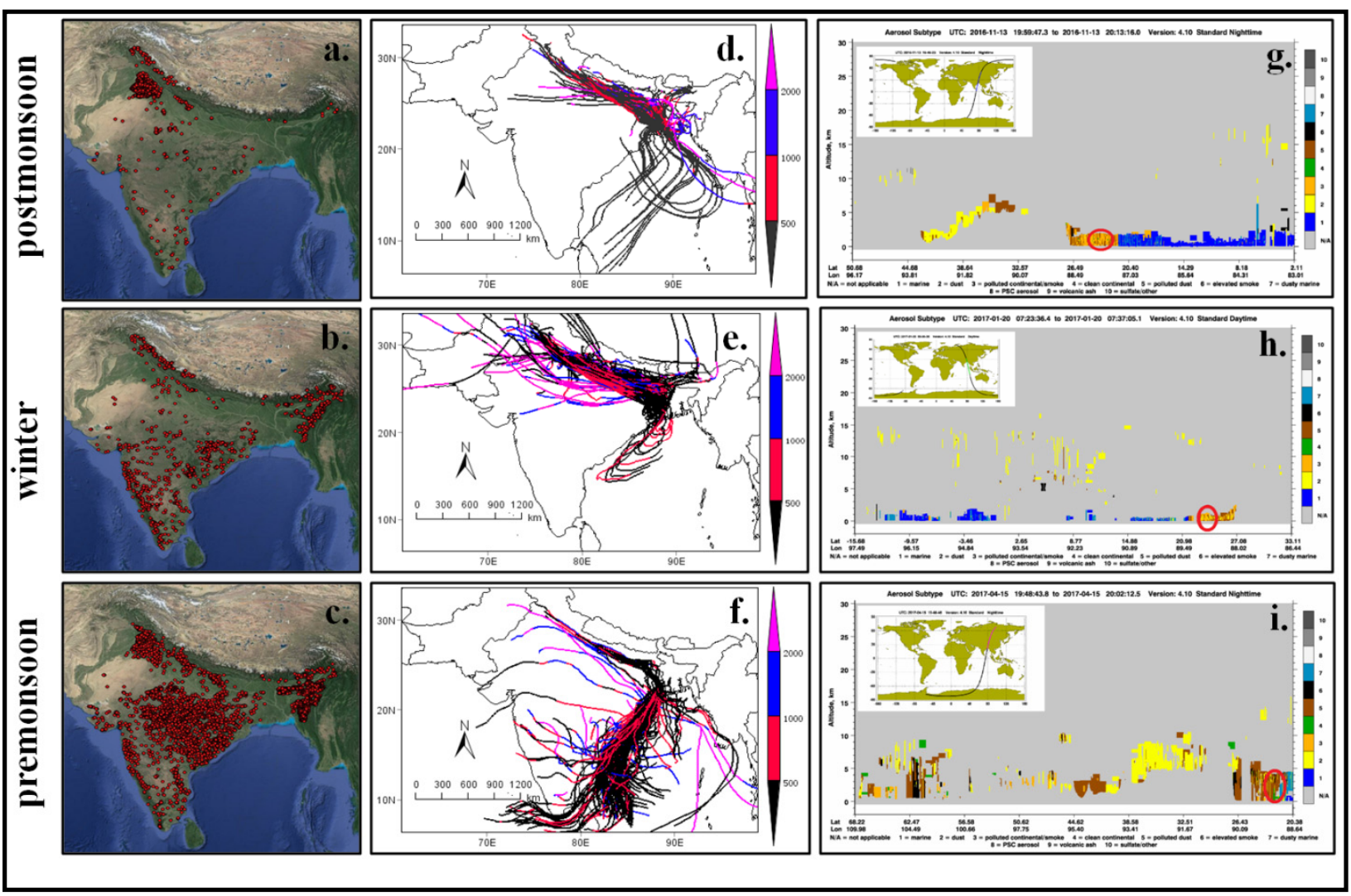

Fig. 4. Satellite data over Kolkata. $(a-c)$ Seasonal active fire counts over India retrieved from MODIS during the study period; (d-f) seasonal air mass back trajectories arriving over Kolkata (culminating at 500m agl), from different altitudes during the sampling dates (purple: above $2000 \mathrm{~m}$ agl; blue: 1000-2000 m agl; red: 500-1000 m agl; black: below $500 \mathrm{~m}$ agl; (g-i) seasonal aerosol vertical profile over Kolkata (red circle) and the satellite paths (insets) during the study period, retrieved from CALIOP. 
plumes from north-western India whereas the layer of the polluted smoke mixed with dust aerosols was present during pre-monsoon. While the layers of polluted smoke during winter and post-monsoon were observed within $2 \mathrm{~km}$ from the ground, the layer of polluted smoke/dust during premonsoon was extended to the higher altitude of around $5 \mathrm{~km}$. Thus, the long-range transport raised PAH loads near the surface during winter and post-monsoon. In fact, large-scale long-range transport of particulates and intrinsic pollutants severely affecting the ambient air qualities of some Chinese megacities have been documented recently (Wang et al., 2017; Jiang and Bai, 2018). On the other hand, despite the closer proximity of the BB source region (Eastern Ghats) to the sampling site, PAH loading during pre-monsoon was the lowest. Thus, it can be inferred that some other factors like micrometeorology and boundary layer dynamics could have played a massive role during pre-monsoon in minimizing the additional burden of the pollutants through long-range transport.

In order to better understand the role of micrometeorology on the PAH loadings during different seasons, the regression analysis has been performed between the meteorological parameters (temperature, solar radiation, wind speed and mixing layer height) and size-segregated PAHs as shown in Fig. 5. The meteorological conditions were quite favorable for the aerosol dispersion during pre-monsoon compared to other seasons (Table 1). The aforementioned meteorological parameters were significantly higher in pre-monsoon. Higher wind speed could easily disperse the pollutants from the sampling site. Charron and Harrison (2005), reported the reduction of fine PM in ambient air of London by $\sim 30 \%$ during strong wind. The regression analysis shows reducing 3,4 and 5,6-PAHs with increasing wind speed. The decrease is much prominent for accumulation mode PAHs. On the contrary, the coarse mode PAHs show little increase in their concentrations with wind speed (slope $=1.3$ and 2.03 for coarse mode 3,4 and 5,6 PAHs respectively and -15.4 and -9.5 for accumulation mode 3,4- and 5,6-PAHs as shown in Fig. 5). This observation is suggestive of higher wind speed leads to fewer inversion situations and better turbulent

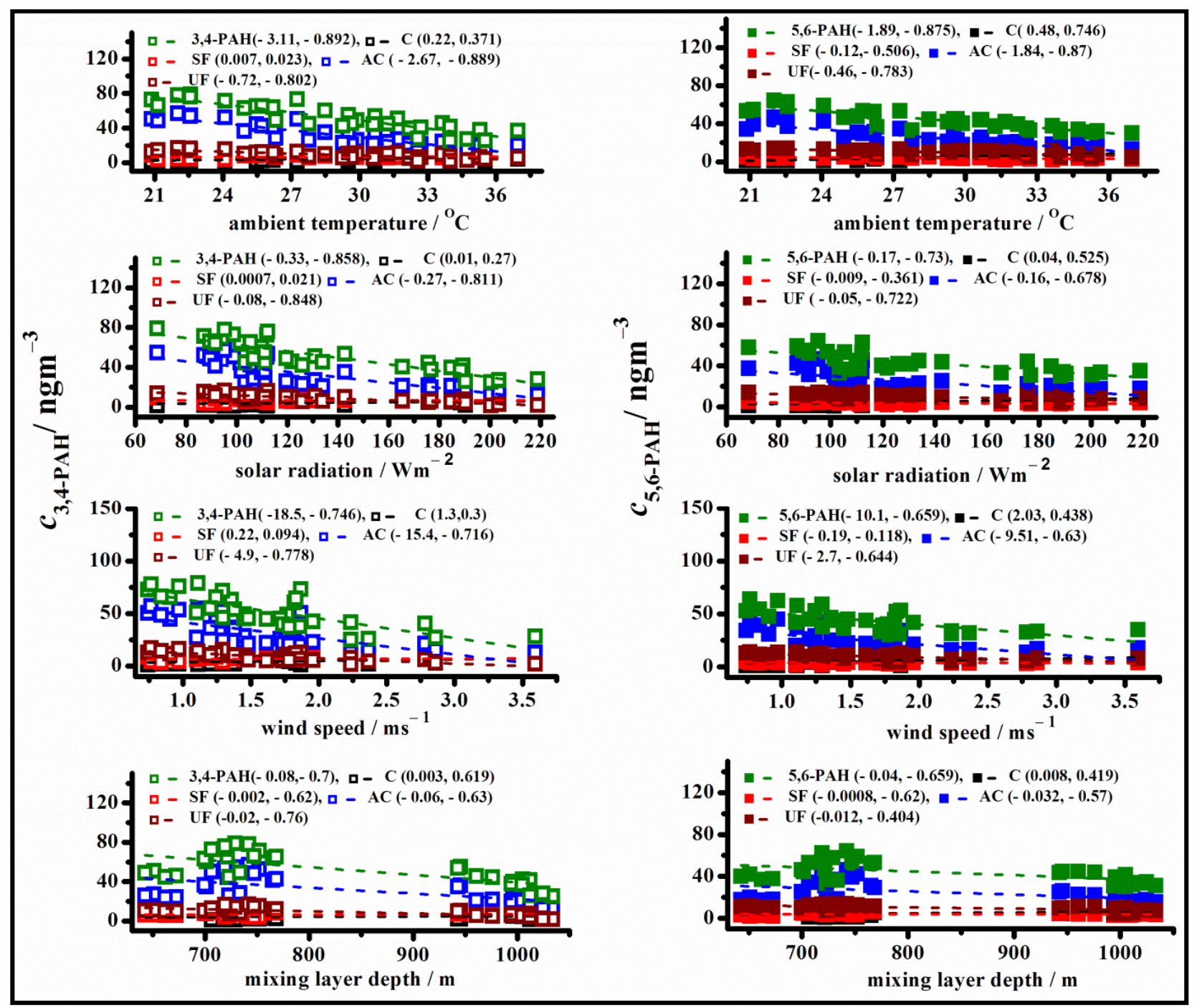

Fig. 5. Regression analysis between micrometeorological parameters and size-specific PAHs. The slope and $r^{2}$ values are given inside bracket in the legends. 
dilution of the smaller sized PAHs especially in the accumulation mode. In fact, smaller PAHs could be easily ventilated and dispersed from the sampling site. The higher temperature and solar radiative fluxes during pre-monsoon (Table 1) further enhanced the lowering of PAHs levels in this season. Significant $(p<0.001)$ decrease in PAH loads with increasing temperature and solar radiation can be observed in Fig. 5, especially in the accumulation mode. On the other hand, similar to the variation with wind speed, coarse mode PAHs shows little growth with temperature and solar radiation. Previous studies showed that PAHs bound to smaller aerosols are more prone to photochemical oxidation under higher temperatures and solar radiation (Srogi, 2007; Kameda et al., 2011), which may lead to significant fall in their loadings. Our earlier studies showed photochemical oxidation of volatile organic compounds and carbonyl compounds over eastern Himalaya and PAHs over Kolkata under higher temperature and solar radiative fluxes (Ray et al., 2017). Substantial impacts of photochemical processes on PM compositions as well as new particle formation have been documented in Los Angeles (Singh et al., 2005), Mexico City (Baumgardner et al., 2004) and Pittsburgh (Stanier et $a l .$, 2004). The higher temperature could also enhance the particle-to-gas phase partitioning leading to a lowering in the particulate PAH load (Monks et al., 2009; Yang et al., 2013). Indeed, the decline in 3,4-PAHs with temperature and solar radiation was faster than the 5,6-PAHs as can be seen from the slopes in Fig. 5, This could be attributed to the more photochemical stability (probably because of higher aromaticity and stronger $\pi-\pi$ stacking with the substrate) of 5,6-PAHs and also the physical and chemical nature of the substrate aerosols (fly ash, dust, etc.) (Chu et al., 2010). The mixed layer depth was maximum during pre-monsoon and much higher than post-monsoon and winter. This is well expected over an urban atmosphere where the mixing layer deepens with the increase in temperature and solar radiation and hence thermal convection. Thus the least loading of PAHs during pre-monsoon could be explained in terms of dilution of the pollutants with the increase in mixing layer height. The regression analysis (Fig. 5) shows that accumulation and ultrafine PAHs (both 3,4 and 5,6-PAHs) decrease with an increase in mixed layer depth whereas coarse mode PAHs show little increase with the increase in mixed layer depth. The higher depth of the mixed layer favors the sampling site to capture the transported pollutants from the long distant sources arriving at comparatively higher altitudes (Fig. 4). As discussed above, higher wind speed also enhanced the coarse mode PAH load over Kolkata. The transport of pollutants from long distant regions could be favored by the higher wind speed. Moisture and hygroscopic (sea-salt) aerosol-laden air masses originating from the Bay of Bengal could have collected particulate PAHs while crossing the fire active Eastern Ghats regions. The smaller aerosols could have transformed into larger particles through coagulation during the transport. Thus it can be inferred that a significant fraction of the coarse mode PAHs could be related to the long-range transport (in addition to the local sources) favored by the higher wind speed as well as higher mixed layer depth. However, TPAH (both 3,4 and 5,6-ring) showed dilution with mixed layer depth. Thus, the meteorology substantially influenced the seasonal variation, especially by diluting the pollutant load during pre-monsoon with higher wind speed, temperature, solar radiation and boundary layer (Elorduy et al., 2016; Wnorowski, 2017). Recently we have observed that the water-soluble ionic components of aerosols in ultrafine and accumulation modes were significantly increased because of transport of pollutants from the Eastern Ghats fire active regions despite the meteorological conditions favorable for the dispersion (Ghosh et al., 2019). On the other hand, in the present study, we observed that meteorology favored the reduction in $\mathrm{PAH}$ loadings and minimized the effect of intrusion of pollutants from the Eastern Ghats regions.

\section{The Size Distribution of PAH to PM Ratio: Probable Mechanisms of Adsorption and Absorption of PAHs}

Assuming the particles are spherical, Venkataraman and coworkers suggested that aerosol surface-bound PAH mass to PM mass ratio should be inversely dependent to particle aerodynamic diameter $\left(D_{\mathrm{p}}\right)$ and the plot of PAH/PM vs. $D_{\mathrm{p}}$ plot on a log-log axis would yield a straight line with a slope of around -1 (Venkataraman et al., 1999). Thus, larger than -1 slope values of all the log-log scale plots of (PAH/PM) vs. $D_{\mathrm{p}}$ in Fig. 6 are opposing the existence of any discrete mechanism; rather suggestive of multiple mechanisms influencing the size-segregated PAH distribution in this urban atmosphere. Similar multiple mechanism driven sizespecific PAH distribution was recently reported in the downtown of Shanghai city (Lv, 2016). In fact, it has long been recognized that PAHs are generated through complex polymerization and condensation reactions during hydrocarbon combustion (Richter and Howard, 2000). The PAHs were proposed to adsorb on ultrafine particles with $D_{\mathrm{p}}$ range of $0.01-0.1 \mu \mathrm{m}$, whereas they can be both adsorbed onto as well as absorbed into the associated organic fractions of fine particles with $D_{\mathrm{p}}$ range of $0.1-2 \mu \mathrm{m}$ and multilayer adsorption onto coarse particles with $D_{\mathrm{p}}$ range of 2-10 $\mu \mathrm{m}$ (Venkataraman et al., 1999, 2002). Relatively higher negative slopes of 5,6$\mathrm{PAH}$ regression lines than that of 3,4-PAHs during all three seasons (Fig. 6) are suggestive of the stronger influence of adsorption on their distribution (Lv et al., 2016). This observation was expected because vapor pressure is negatively correlated to molecular weight (Keyte et al., 2013), thereby slowing down the 5,6-PAH mass transfer. Both 3,4 and 5,6PAHs showed the same trends of the slopes of their regression lines during all three seasons which can be due to the enrichment of unit mass of PM by PAHs in respective seasons and these specific patterns are the characteristics of size-specific PAHs over Kolkata. However, during premonsoon, the slopes of the regression lines were found to be the least. As discussed in the earlier section the smaller sized PAHs under higher temperature and solar radiation during pre-monsoon could get photochemically oxidized and form secondary organic aerosols. These secondary aerosols could further increase the PM concentration and hence lower the $\mathrm{PAH} / \mathrm{PM}$ ratio at the accumulation mode. Again, the coarse mode PAHs increased during pre-monsoon probably due to the size enhancement of smaller aerosols through coagulation during transport leading to increased $\mathrm{PAH} / \mathrm{PM}$ ratio at the 


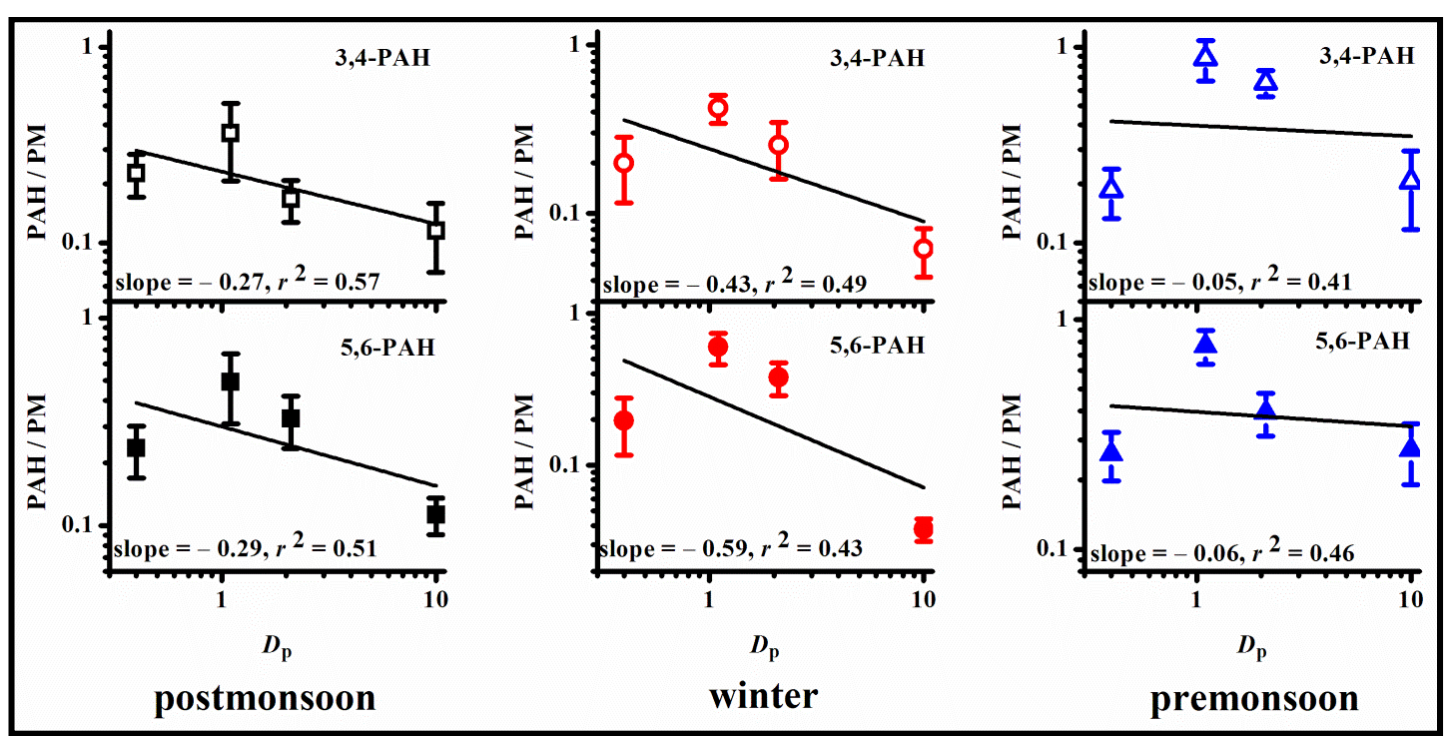

Fig. 6. Seasonal plot of (PAH/PM) vs. $D_{\mathrm{p}}$ in log-log scale for 3,4-PAHs and 5,6-PAHs. Error bars represent standard deviations.

coarse mode. Also, this could lead to the lowering of the slopes of the regression lines during pre-monsoon both for 3,4 and 5,6-PAHs.

\section{Source Apportionment of Particulate PAHs by PMF}

Possible emission sources of particulate PAHs in the ambient air of Kolkata were carried out by using EPA PMF 5.0 software. A five-factor model was chosen as the optimal solution for the PMF analysis of size-segregated PAHs. The factor profiles describing individual $\mathrm{PAH}$ percentage contribution to each factor or source for coarse, superfine, accumulation and ultrafine PM have been shown in Fig. S2. The identified probable emission sources or factors were combustion of coal, petrol, diesel, municipal solid waste incineration, and unburned petroleum. Several studies reported that the PAH profile from coal combustion varies with combustion conditions and type of coal (Chen et al., 2005). However, 3,4-PAHs and some 5,6-PAHs like BbF, BkF, and BghiP were identified as the predominant components in coal combustion emission (Yunker et al., 2002; Larsen and Baker, 2003; Lee et al., 2005; Pergal et al., 2013; Hsu et al., 2016). Thus major contributions of PYR, BaA, CHRY, BbF, BghiP, and moderate contributions of PHE, ANT, and FLT indicate factor-1 might be coal combustion. Heavier PAHs especially BghiP and IP were reported as typical petrol combustion indicators (Ho et al., 2009). Additionally, BaP, BaA, and CHRY were also identified as tracers of petrol combustion (Dickhut et al., 2000; Dzepina et al., 2007). In the present study, factor-2 is mainly enriched with heavier PAHs such as BghiP, IP, BaP. Moderate to trace contributions of lighter 3,4-PAHs were also observed in this factor. Thus, factor-2 indicates petrol combustion as another possible source of PAHs. The major identified components of diesel combustion are PHE, ANT, FLT, PYR, BaA, CHRY, BbF, BkF and $\mathrm{BaP}$. In fact, $\mathrm{B}(\mathrm{b}+\mathrm{k}) \mathrm{F}$ and $\mathrm{FLT}, \mathrm{PYR}$ were reported as markers of diesel exhaust emission(Ho et al., 2009). In fact, low molecular weights PAHs were measured in excess in the routes dominated by diesel vehicles (Kuo et al., 2013). Thus, the predominance of these PAHs as major components of factor-3 indicates the source can be diesel combustion. A considerable amount of PAHs and other harmful products like dioxins and heavy metals are emitted into urban air from solid waste incineration which is very common in developing countries where urban waste recycling is not a common practice mainly due to lack of proper technologies. The solid wastes include mainly paper, plastics, rubber products, wood and agricultural residue. Several studies reported release of ANT, PHE, FLT, PYR, BaA, BaP, BghiP and IP from municipal solid waste incineration, plastic burning and fly ash from agricultural residue burning (Li et al., 2001; Mi et al., 2001; Kakareka and Kukharchyk, 2003; Park et al., 2013). Therefore, the profile composed of mainly 3,4-PAHs like PHE, PYR, BaA, CHRY and 5,6-PAHs like BaP, IP and BghiP indicates factor- 4 as the possible $\mathrm{PAH}$ source from municipal solid waste incineration, wood, and BB. Factor-5 is enriched mainly with 3,4-PAHs such as PHE, ANT, FLT, PYR, and BaA. Additionally, ACY, ACE, FLU, BghiP, and IP contributed moderately to factor-5. High loading of PHE and its derivatives were attributed to unburned petroleum from vehicles (Zuo et al., 2007; Jang et al., 2013). Also, several studies reported majorly low molecular weight PAHs to arise by evaporation of petroleum residue or fuel leaked from vehicles mainly by evaporation (Ravindra et al., 2008; Lv et al., 2016). Thus, factor-5 seems to represent unburned petroleum as another source of PAHs.

Fig. 7 describes the relative contributions of the possible PAH emission sources for each mode of associating PM. Coal-burning emissions majorly yielded ultrafine PAHs and the percentage contribution decreased with increasing aerodynamic diameter of PM, whereas the opposite trend was observed for PAHs from unburned petroleum. These results are expected because coarse mode PM is derived from soil, minerals and PAHs are partitioned onto coarse PM mainly by dry deposition and the re-adsorption of 


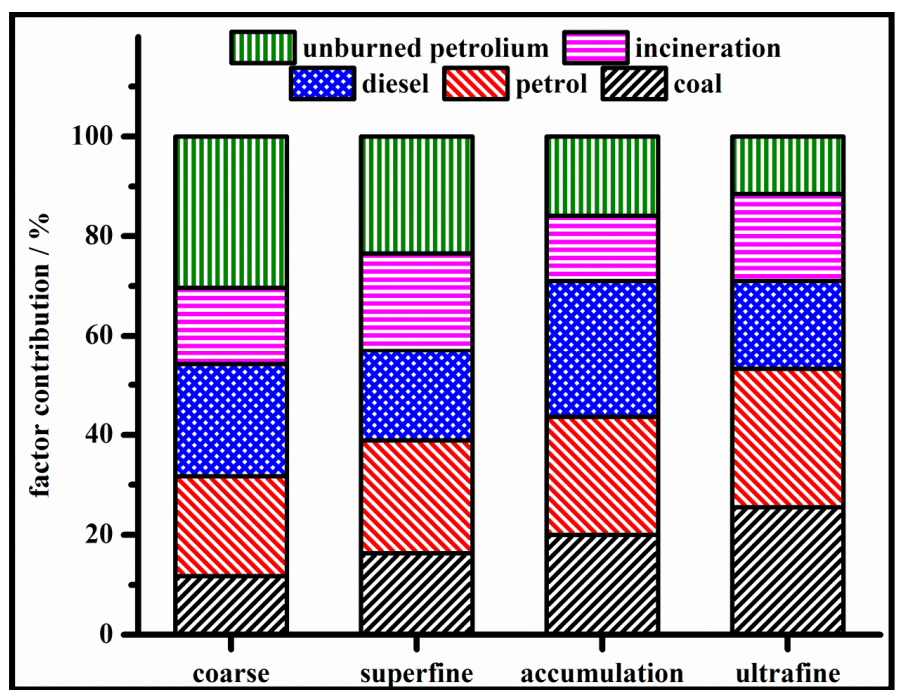

Fig. 7. Relative contributions of factors/sources to different size modes.

gaseous and evaporated ultrafine PAHs by the larger coarse mode aerosols. Comparing with some of the recent studies conducted in other megacities of India like Delhi (Gadi et al., 2019) and Mumbai (Masih et al., 2019), the percentage contribution of PAHs from vehicular emission (including diesel and petrol combustion) has been found to be the highest in the finer aerosols as also observed in the present study in Kolkata. The PAHs emitted from municipal solid waste and biomass incineration were mostly associated with superfine mode PM, whereas its lowest contribution was observed for accumulation mode PAHs.

\section{Inhalation Risk Assessment}

\section{Size-segregated Particulate PAH}

The current study quantified $50-65 \%$ carcinogenic and mutagenic PAHs in the PM including $\mathrm{BaP}, \mathrm{BaA}, \mathrm{CHRY}$, $\mathrm{BbF}, \mathrm{BkF}$, DBA, DBaiP, DMBA and IP (IARC, 2006). The result is a slight increase in particulate $\mathrm{PAH}$ mass measured in our previous study (Ray et al., 2017). Similar to other studies, our results also indicate that carcinogenic PAHs are more prone to adsorb onto finer particles, which is a serious source of concern for a metro city. In fact, the seasonal sizespecific concentrations of Bap eq reveal (Fig. S3) extensive amassment of carcinogenic PAHs in accumulation and ultrafine PM during all three seasons and the values are significantly higher than the recommended National Ambient Air Quality Standards (NAAQS) limit of $1 \mathrm{ng} \mathrm{m}^{-3}$ (MoEF, 2009), particularly during winter. Additionally, we estimated the incremental lifetime cancer risk (ILCR) due to inhalation for four representative age groups such as preschool (25 years), school-goers (5-18 years), working (18-60 years) and retired (60-70 years) as demonstrated in Fig. 8. Similar to the observations by Lv et al. (2016), the accumulation PM is the major carrier of carcinogenic PAHs contributing maximum to the ILCR estimation. Clearly, the preschool age group cannot be considered under risk as the corresponding estimated ILCR values are significantly below the carcinogenic benchmark level of $1 \times 10^{-6}$, whereas the school goers and retired age groups were also mostly below the threshold value. On the other hand, relatively higher values were estimated for the working-age group especially during winter. A limited number of studies in the Indian scenario have been reported estimating the cancer risk due to inhalation. For example, Jyethi and coworkers reported the ILCR $=3.18 \times$ $10^{-6}$ for school-children of Delhi (Jyethi et al., 2014), whereas almost double in the magnitude of ILCR was reported for adults $\left(7.23 \times 10^{-6}\right)$ and children $\left(7.43 \times 10^{-6}\right)$ in Amritsar, India (Kaur et al., 2013). Recently, Hazarika et al. (2019) reported the $\mathrm{ILCR}_{\text {children }(6 \text { years })}=4.36 \times 10^{-6}$ and $1.93 \times 10^{-6}$ and $\mathrm{ILCR}_{\text {adults }}\left(40\right.$ years) $=4.84 \times 10^{-6}$ and $2.15 \times 10^{-6}$ in Delhi for eight-PAHs bound to fine and coarse mode particles, respectively.

\section{Combining Gaseous and Particulate PAHs}

We have estimated the ILCR values for the combined gaseous and particulate PAHs. For the particulate PAHs, we have taken PAHs in $\mathrm{PM}_{10}$ (summing up all the size-segregated stages) from the present study. On the other hand, because of sampling limitations, we have taken the gaseous PAHs concentrations from the study conducted by Saha et al. (2017) over the similar atmospheric environment over Kolkata. We have considered the PAHs that were common in both the studies. The ILCR values estimated for the pre-school, school-goers, working and retired population in Kolkata were $5.33 \times 10^{-7}, 1.83 \times 10^{-6}, 7.36 \times 10^{-6}$ and $1.73 \times 10^{-6}$, respectively. The results do not suggest any significant enhancement of the risk due to inclusion of the gaseous PAH concentrations in the ILCR estimation ( $\mathrm{Qu}$ et al., 2015). This, in turn, indicates that the human health is more vulnerable to particulate $\mathrm{PAH}$ pollution rather than gaseous PAH over Kolkata. The dermal and ingestion exposure routes (Anderson and Meade, 2014; Rengarajan et al., 2015) and the genetic parameters of the population (Shen et al., 2014) could also be taken into account for more precise risk assessment. However, inclusions of these factors were beyond the scope of this study and we hope to carry out more precise estimations of ILCR in the future. 


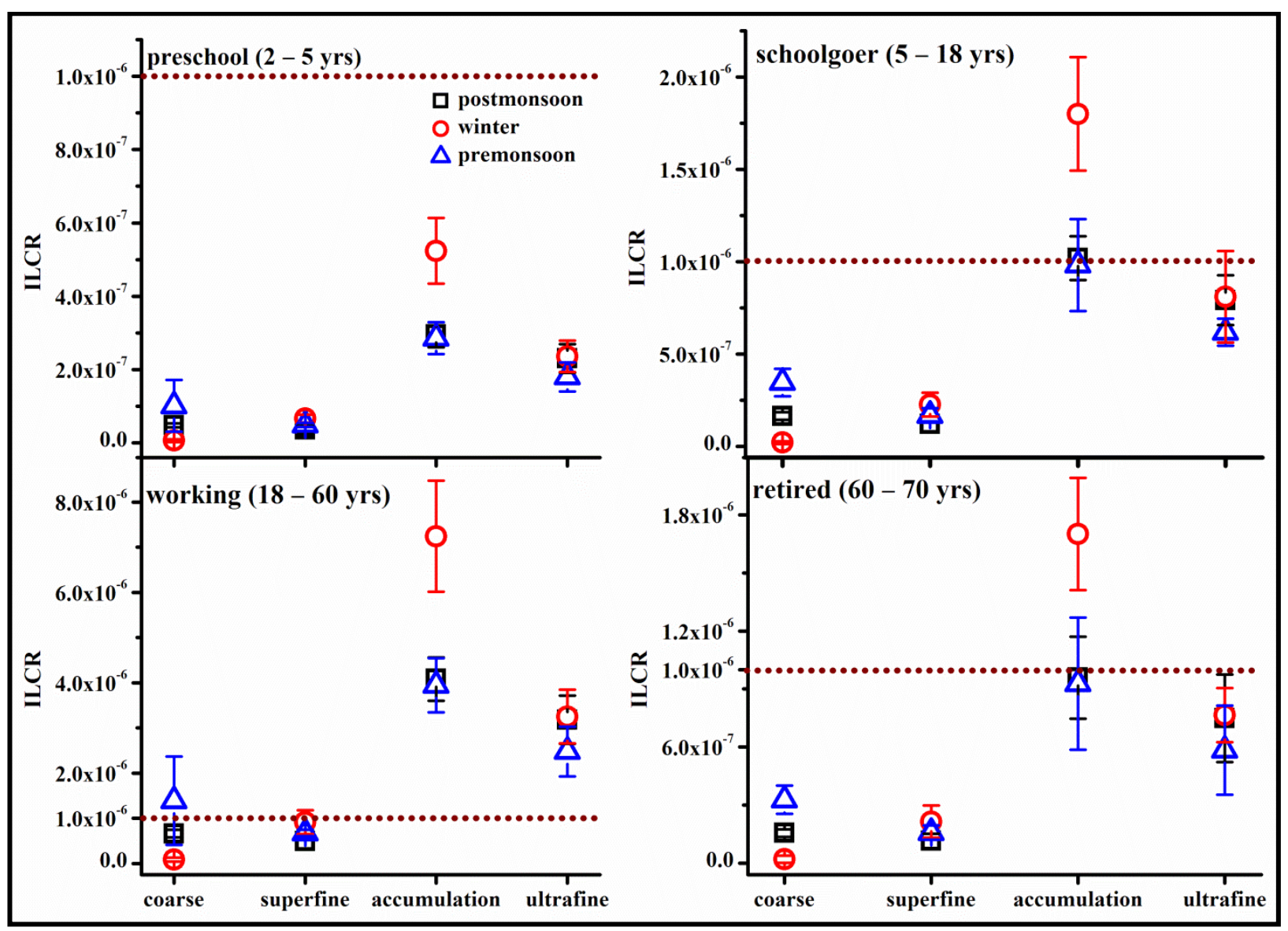

Fig. 8. Seasonal size-specific incremental lifetime cancer risk (ILCR) values for the four age groups. Error bars represent standard deviations.

\section{CONCLUSIONS}

The findings of this study demonstrate that the major sources of PAHs over Kolkata were unburned petroleum, solid waste incineration, petrol, diesel, and coal burning. Coal-burning contributed more to the smaller PAHs whereas unburned petroleum contributed more to the larger PAHs. In addition to the local anthropogenic urban activities, the PAH load over a tropical urban atmosphere like Kolkata could be greatly influenced by the long-range transport as well as the boundary-layer dynamics and the prevailing meteorological conditions. It was observed that the accumulation of PAHs from both the local emissions and long-range transport over Kolkata was favored by meteorological and boundary layer conditions during relatively colder seasons, such as postmonsoon and winter. On the other hand, during pre-monsoon, meteorology played a great role to diminish and hence dilute the PAH levels despite the influence of advected aerosols from the long-distant regions. In addition, the findings are suggestive of multiple mechanisms controlling the size-specific distribution of PAHs in a complex system of an urban atmosphere. Moreover, the estimated ILCR values indicate that the working-age group is under relatively more risk than the retired and school goers, especially during winter. However, this study has three shortcomings. Firstly, we were unable to take the gas phase PAHs into consideration because it is beyond the scope of this research. Therefore, the concentration values in this study could be representing the lower limit. However, utilizing the gaseous PAH concentration from a previous measurement by Saha et al. (2017), we have estimated the ILCR values for the combined gaseous and particulate PAHs. We have found that the human health is more vulnerable to particulate PAH pollution rather than gaseous PAH over Kolkata. Secondly, the number of samplings could be limited because we performed only 32 samplings, once a week for eight months. However, each event took 72 hours of continuous sampling since relatively long sampling time is required to collect sufficient mass of atmospheric nanoparticles. Lastly, the smallest cut-off point of PM aerodynamic diameter in this study was $400 \mathrm{~nm}$. However, ultrafine aerosols are particularly important in terms of health risk because they are small enough to reach the alveoli and then to the blood. Thus, in the future, we hope to carry out the study by enlarging the sampling size and lowering the cut-off limit of accumulated particle aerodynamic diameter.

\section{ACKNOWLEDGMENTS}

Authors would like to thank Science and Engineering Board, Department of Science and Technology, Government of India for supporting the study under IRHPA (Intensification of Research in High Priority Areas) scheme (Grant 
no. IR/S2/PF - 01/2011 dated 26.06.2012). The authors are grateful to Dr. Anandamay Adak for logistic supports and Mr. Swaroop Biswas for HPLC measurements.

\section{CONFLICT OF INTEREST}

The authors declare they have no actual or potential competing financial interests.

\section{AUTHOR CONTRIBUTION}

DR designed the work; AG collected samples; DR performed chemical analysis; AG, DR \& AC interpreted the results and wrote the original manuscript, which was finalized after critical comments by SR \& SKG.

\section{SUPPLEMENTARY MATERIAL}

Supplementary data associated with this article can be found in the online version at http://www.aaqr.org.

\section{REFERENCES}

Al-Daghri, N.M., Alokail, M.S., Abd-Alrahman, S.H., Draz, H.M., Yakout, S.M. and Clerici, M. (2013). Polycyclic aromatic hydrocarbon exposure and pediatric asthma in children: A case-control study. Environ. Health 12: 1. doi: $10.1186 / 1476-069 x-12-1$

Allen, J.O., Dookeran, N.M., Smith, K.A., Sarofim, A.F., Taghizadeh, K. and Lafleur, A.L. (1996). Measurement of polycyclic aromatic hydrocarbons associated with sizesegregated atmospheric aerosols in Massachusetts. Environ. Sci. Technol. 30: 1023-1031. doi: 10.1021/es950517o

Anderson, S.E. and Meade, B.J. (2014). Potential health effects associated with dermal exposure to occupational chemicals. Environ. Health Insights 8: 51-62. doi: 10.4137/ehi.s15258

Barbas, B., de la Torre, A., Sanz, P., Navarro, I., Artínano, B. and Martínez, M.A. (2018). Gas/particle partitioning and particle size distribution of PCDD/Fs and PCBs in urban ambient air. Sci. Total Environ. 624: 170-179. doi: 10.1016/j.scitotenv.2017.12.114

Baumgardner, D., Raga, G.B. and Muhlia, A. (2004). Evidence for the formation of $\mathrm{CCN}$ by photochemical processes in Mexico City. Atmos. Environ. 38: 357-367. doi: 10.1016/j.atmosenv.2003.10.008

Boada, L.D., Henriquez-Hernandez, L.A., Navarro, P., Zumbado, M., Almeida-Gonzalez, M., Camacho, M., Álvarez-León, E.E., Valencia-Santana, J.A. and Luzardo, O.P. (2015). Exposure to polycyclic aromatic hydrocarbons (PAHs) and bladder cancer: Evaluation from a geneenvironment perspective in a hospital-based case-control study in the Canary Islands (Spain). Int. J. Occup. Environ. Health 21: 23-30. doi: 10.1179/2049396714y.0 000000085

Burstyn, I., Kromhout, H., Partanen, T., Svane, O., Langard, S., Ahrens, W., Kauppinen, T., Stücker, I., Shaham, J., Heederik, D., Ferro, G., Heikkilä, P., Hooiveld, M., Johansen, C., Randem, B.G and Boffetta, P. (2005).
Polycyclic aromatic hydrocarbons and fatal ischemic heart disease. Epidemiology 16: 744-750. doi: 10.1097/0 1.ede. $0000181310.65043 .2 \mathrm{f}$

Callén, M.S., Iturmendi, A., López, J.M. and Mastral, A.M. (2014). Source apportionment of the carcinogenic potential of polycyclic aromatic hydrocarbons (PAH) associated to airborne $\mathrm{PM}_{10}$ by a PMF model. Environ. Sci. Pollut. Res. 21: 2064-2076. doi: 10.1007/s11356-013-2116-9

Charron, A. and Harrison, R.M. (2005). Fine $\left(\mathrm{PM}_{2.5}\right)$ and coarse $\left(\mathrm{PM}_{2.5-10}\right)$ particulate matter on a heavily trafficked London highway: Sources and processes. Environ. Sci. Technol. 39: 7768-7776. doi: 10.1021/es050462i

Chatterjee, A., Dutta, C., Jana, T.K. and Sen, S. (2012). Fine mode aerosol chemistry over a tropical urban atmosphere: Characterization of ionic and carbonaceous species. $J$. Atmos. Chem. 69: 83-100. doi: 10.1007/s10874-0129231-8

Chen, S.C. and Liao, C.M. (2006). Health risk assessment on human exposed to environmental polycyclic aromatic hydrocarbons pollution sources. Sci. Total Environ. 366: 112-123. doi: 10.1016/j.scitotenv.2005.08.047

Chen, Y., Sheng, G., Bi, X., Feng, Y., Mai, B. and Fu, J. (2005). Emission factors for carbonaceous particles and polycyclic aromatic hydrocarbons from residential coal combustion in China. Environ. Sci. Technol. 39: 18611867. doi: 10.1021/es0493650

Choi, H., Wang, L., Lin, X., Spengler, J.D. and Perera, F.P. (2012). Fetal Window of vulnerability to airborne polycyclic aromatic hydrocarbons on proportional intrauterine growth restriction. PLoS One 7:e35464. doi: 10.1371/journal.pone.0035464

Chu, S.N., Sands, S., Tomasik, M.R., Lee, P.S. and McNeill, V.F. (2010). Ozone oxidation of surface-adsorbed polycyclic aromatic hydrocarbons: Role of $\mathrm{PAH}-$ surface interaction. J. Am. Chem. Soc. 132: 15968-15975. doi: $10.1021 /$ ja1014772

Dennekamp, M. and Abramson, M.J. (2011). The effects of bushfire smoke on respiratory health. Respirolog. 16: 198-209. doi: 10.1111/j.1440-1843.2010.01868.x

Dickhut, R.M., Canuel, E.A., Gustafson, K.E., Liu, K., Arzayus, K.M., Walker, S.E., Edgecombe, G., Gaylor, M.O. and MacDonald, E.H. (2000). Automotive sources of carcinogenic polycyclic aromatic hydrocarbons associated with particulate matter in the Chesapeake bay region. Environ. Sci. Technol. 34: 4635-4640. doi: 10.1021/ es000971e

Dzepina, K., Arey, J., Marr, L.C., Worsnop, D.R., Salcedo, D., Zhang, Q., Onasche T.B., Molina L.T., Molina M.J. and Jimenez, J.L. (2007). Detection of particle-phase polycyclic aromatic hydrocarbons in Mexico City using an aerosol mass spectrometer. Int. J. Mass Spectrom. 263: 152-170. doi: 10.1016/j.ijms.2007.01.010

Elorduy, I., Elcoroaristizabal, S., Durana, N., García, J.A. and Alonso, L. (2016). Diurnal variation of particlebound PAHs in an urban area of Spain using TD-GC/MS: Influence of meteorological parameters and emission sources. Atmos. Environ. 138: 87-98. doi: 10.1016/j.atmo senv.2016.05.012

Friedman, C.L. and Selin, N.E. (2012). Long-range 
atmospheric transport of polycyclic aromatic hydrocarbons: A global 3-D model analysis including evaluation of Arctic sources. Environ. Sci. Technol. 46: 9501-9510. doi: 10.1021/es301904d

Gadi, R., Shivani, Sharma, S.K. and Mandal, T.K. (2019). Source apportionment and health risk assessment of organic constituents in fine ambient aerosols $\left(\mathrm{PM}_{2.5}\right)$ : A complete year study over National Capital Region of India. Chemosphere 221: 583-596. doi: 10.1016/j.chemo sphere.2019.01.067

Gao, B., Wang, X.M., Zhao, X.Y., Ding, X., Fu, X.X., Zhang, Y.L., He, Q.F., Zhang, Z., Liu, T.Y., Huang, Z.Z., Chen, L.G., Peng, Y. and Guo, H. (2015). Source apportionment of atmospheric PAHs and their toxicity using PMF: Impact of gas/particle partitioning. Atmos. Environ. 103: 114-120. doi: 10.1016/j.atmosenv.2014.12. 006

Ghosh, A., Roy, A., Chatterjee, A., Das, S.K., Ghosh, S.K. and Raha, S. (2019). Impact of biomass burning plumes on the size-segregated aerosol chemistry over an urban atmosphere at Indo-Gangetic Plain. Aerosol Air Qual. Res. 19: 163-180. doi: 10.4209/aaqr.2017.12.0590

Haiba, N.S. and Hassan, I.A. (2018). Monitoring and assessment of polycyclic aromatic hydrocarbons (PAHs) in the atmosphere of Alexandria city, Egypt. Polycyclic Aromat. Compd. 38: 219-230, doi: 10.1080/10406638.20 16.1200102

Haikerwal, A., Akram, M., Del Monaco, A., Smith, K., Sim, M.R., Meyer, M., Tonkin A.M., Abramson M.J. and Dennekamp, M. (2015). Impact of fine particulate matter $\left(\mathrm{PM}_{2.5}\right)$ exposure during wildfires on cardiovascular health outcomes. J. Am. Heart Assoc. 4: e001653 doi: 10.1161/jaha.114.001653.

Hazarika, N., Das, A., Kamal, V., Anwar, K., Srivastava, A. and Jain, V.K. (2019). Particle phase PAHs in the atmosphere of Delhi-NCR: With spatial distribution, source characterization and risk approximation. Atmos. Environ. 200: 329-342. doi: 10.1016/j.atmosenv.2018.11. 064

Ho, K.F., Ho, S.S.H., Lee, S.C., Cheng, Y., Chow, J.C., Watson, J.G., Louie P.K.K. and Tian, L. (2009). Emissions of gas- and particle-phase polycyclic aromatic hydrocarbons (PAHs) in the Shing Mun Tunnel, Hong Kong. Atmos. Environ. 43: 6343-6351. doi: 10.1016/j.atmosenv.2009.0 9.025

Hopke, P. (2000). A guide to positive matrix factorization. EPA Workshop Proceedings Materials from the Workshop on UNMIX and PMF as Applied to $\mathrm{PM}_{2.5}$.

Hoseini, M., Yunesian, M., Nabizadeh, R., Yaghmaeian, K., Ahmadkhaniha, R., Rastkari, N., Parmy, S., Faridi, S., Rafiee, A. and Naddafi, K. (2016). Characterization and risk assessment of polycyclic aromatic hydrocarbons (PAHs) in urban atmospheric Particulate of Tehran, Iran. Environ. Sci. Pollut. Res. 23: 1820-1832. doi: 10.1007/s11356-015-5355-0

Hsu, W.T., Liu, M.C., Hung, P.C., Chang, S.H. and Chang, M.B. (2016). PAH emissions from coal combustion and waste incineration. J. Hazard. Mater. 318: 32-40. doi: 10.1016/j.jhazmat.2016.06.038
Hu, R., Liu, G., Zhang, H., Xue, H. and Wang, X. (2017). Levels and sources of PAHs in air-borne $\mathrm{PM}_{2.5}$ of Hefei city, China. Bull. Environ. Contam. Toxicol. 98: 270-276. doi: 10.1007/s00128-016-2019-9

IARC (International Agency for Research on Cancer) (2006). Polycyclic Aromatic Hydrocarbons, IARC Monographs 92, 2006, Lyon, France, http://monographs.iarc.fr/ENG/ Meetings/92-pahs.pdf.

Jain, N., Bhatia, A. and Pathak, H. (2014). Emission of air pollutants from crop residue burning in India. Aerosol Air Qual. Res. 14: 422-430. doi: 10.4209/aaqr.2013.01.0031

Jang, E., Alam, M.S. and Harrison, R.M. (2013). Source apportionment of polycyclic aromatic hydrocarbons in urban air using positive matrix factorization and spatial distribution analysis. Atmos. Environ. 79: 271-285. doi: 10.1016/j.atmosenv.2013.06.056

Jiang, L. and Bai, L. (2018). Spatio-temporal characteristics of urban air pollutions and their causal relationships: Evidence from Beijing and its neighboring cities. Sci. Rep. 8: 1279. doi: 10.1038/s41598-017-18107-1

Jyethi, D.S., Khillare, P.S. and Sarkar, S. (2014). Risk assessment of inhalation exposure to polycyclic aromatic hydrocarbons in school children. Environ. Sci. Pollut. Res. Int. 21: 366-378. doi: 10.1007/s11356-013-1912-6

Kajiwara, T., Ogami, A., Yamato, H., Oyabu, T., Morimoto, Y. and Tanaka, I. (2007). Effect of particle size of intratracheally instilled crystalline silica on pulmonary inflammation. J. Occup. Health 49: 88-94.

Kakareka, S.V. and Kukharchyk, T.I. (2003). PAH emission from the open burning of agricultural debris. Sci. Total Environ. 308: 257-261. doi: 10.1016/S0048-9697(02)006 50-2

Kalisa, E., Nagato, E.G., Bizuru, E., Lee, K.C., Tang, N., Pointing, S.B., Hayakawa, K., Archer, S.D.J. and LacapBugler D.C. (2018). Characterization and risk assessment of atmospheric $\mathrm{PM}_{2.5}$ and $\mathrm{PM}_{10}$ particulate-bound PAHs and NPAHs in Rwanda, central-east Africa. Environ. Sci. Technol. 52: 12179-12187. doi: 10.1021/acs.est.8b03219

Kameda, T., Akira, A., Toriba, A., Tang, N. and Hayakawa, K. (2011). Atmospheric chemistry of polycyclic aromatic hydrocarbons and related compounds. J. Health Sci. 57: 504-511. doi: 10.1248/jhs.57.504

Karimi, P., Peters, K.O., Bidad, K. and Strickland, P.T. (2015). Polycyclic aromatic hydrocarbons and childhood asthma. Eur. J. Epidemiol. 30: 91-101. doi: 10.1007/s106 54-015-9988-6

Kaur, S., Senthilkumar, K., Verma, V.K., Kumar, B., Kumar, S., Katnoria, J.K. and Sharma, C.S. (2013). Preliminary analysis of polycyclic aromatic hydrocarbons in air particles $\left(\mathrm{PM}_{10}\right)$ in Amritsar, India: sources, apportionment, and possible risk implications to humans. Arch. Environ. Contam. Toxicol. 65: 382-395. doi: 10.1007/s00244-0139912-6

Keyte, I.J., Harrison, R.M. and Lammel, G. (2013). Chemical reactivity and long-range transport potential of polycyclic aromatic hydrocarbons - A review. Chem. Soc. Rev. 42: 9333-9391. doi: 10.1039/C3CS60147A

Kuo, C.Y., Chien, P.S., Kuo, W.C., Wei, C.T. and Rau, J.Y. (2013). Comparison of polycyclic aromatic hydrocarbon 
emissions on gasoline- and diesel-dominated routes. Environ. Monit. Assess. 185: 5749-5761. doi: 10.1007/s1 0661-012-2981-6

Lammel, G., Sehili, A.M., Bond, T.C., Feichter, J. and Grassl, H. (2009). Gas/particle partitioning and global distribution of polycyclic aromatic hydrocarbons - A modelling approach. Chemosphere 76: 98-106. doi: 10.1016/j.chemosphere.2009.02.017

Larsen, A.E., Reich, B.J., Ruminski, M. and Rappold, A.G. (2017). Impacts of fire smoke plumes on regional air quality, 2006-2013. J. Exposure Sci. Environ. Epidemiol. 28: 319-328. doi: 10.1038/s41370-017-0013-x

Larsen, R.K. and Baker, J.E. (2003). Source apportionment of polycyclic aromatic hydrocarbons in the urban atmosphere: A comparison of three methods. Environ. Sci. Technol. 37: 1873-1881. doi: 10.1021/es0206184

Lee, B.C., Shimizu, Y., Matsuda, T. and Matsui, S. (2005). Characterization of polycyclic aromatic hydrocarbons (PAHs) in different size fractions in deposited road particles (DRPs) from Lake Biwa Area, Japan. Environ. Sci. Technol. 39: 7402-7409. doi: 10.1021/es050103n

Li, C.T., Zhuang, H.K., Hsieh, L.T., Lee, W.J. and Tsao, M.C. (2001). PAH emission from the incineration of three plastic wastes. Environ. Int. 27: 61-67. doi: 10.1016/S01 60-4120(01)00056-3

Liu, B., Wu, J., Zhang, J., Wang, L., Yang, J., Liang, D., Dai, Q., Bi, X., Feng, Y., Zhang, Y. and Zhang, Q. (2017). Characterization and source apportionment of $\mathrm{PM}_{2.5}$ based on error estimation from EPA PMF 5.0 model at a medium city in China. Environ. Pollut. 222: 10-22. doi: 10.1016/j.envpol.2017.01.005

Lv, Y., Li, X., Xu, T.T., Cheng, T.T., Yang, X., Chen, J.M., Iinuma, Y. and Herrmann, H. (2016). Size distributions of polycyclic aromatic hydrocarbons in urban atmosphere: Sorption mechanism and source contributions to respiratory deposition. Atmos. Chem. Phys. 16: 29712983. doi: 10.5194/acp-16-2971-2016

Masih, J., Dyavarchetti, S., Nair, A., Taneja, A. and Singhvi, R. (2019). Concentration and sources of fine particulate associated polycyclic aromatic hydrocarbons at two locations in the western coast of India. Environ. Technol. Inno. 13: 179-188.

Mi, H.H., Chiang, C.F., Lai, C.C., Wang, L.C. and Yang, H.H. (2001). Comparison of PAH emission from a municipal waste incinerator and mobile sources. Aerosol Air Qual. Res. 1: 83-90.

MoEF (Ministry of Environment and Forests) (2009). Environment (Protection) Seventh Amendment Rules. Ministry of Environment and Forests. Government of India Press, New Delhi.

Monks, P.S., Granier, C., Fuzzi, S., Stohl, A., Williams, M. L., Akimoto, H., et al. (2009). Atmospheric composition change - global and regional air quality. Atmos. Environ. 43: 5268-5350. doi: 10.1016/j.atmosenv.2009.08.021

Monsalve, F., Tomás, C. and Fraile, R. (2013). Influence of meteorological parameters and air pollutants onto the morbidity due to respiratory diseases in Castilla- La Mancha, Spain. Aerosol Air Qual. Res. 13: 1297-1312. doi: 10.4209/aaqr.2012.12.0348
Nisbet, I.C.T. and LaGoy, P.K. (1992). Toxic equivalency factors (TEFs) for polycyclic aromatic hydrocarbons (PAHs). Regul. Toxicol. Pharm. 16: 290-300. doi: 10.1016/0273-2300(92)90009-X

Paatero, P. and Tapper, U. (1994). Positive matrix factorization: A non-negative factor model with optimal utilization of error estimates of data values. Environmetrics 5: 111-126. doi: 10.1002/env.3170050203

Park, Y.K., Kim, W. and Jo, Y.M. (2013). Release of harmful air pollutants from open burning of domestic municipal solid wastes in a metropolitan area of Korea. Aerosol Air Qual. Res. 13: 1365-1372. doi: 10.4209/aaqr. 2012.10.0272

Pergal, M.M., Tešić, Ž.L. and Popović, A.R. (2013). Polycyclic aromatic hydrocarbons: Temperature driven formation and behavior during coal combustion in a coalfired power plant. Energy Fuels 27: 6273-6278. doi: 10.1021/ef401467z

Polanska, K., Dettbarn, G., Jurewicz, J., Sobala, W., Magnus, P., Seidel, A. and Hanke, W. (2014). Effect of prenatal polycyclic aromatic hydrocarbons exposure on birth outcomes: The Polish mother and child cohort study. Biomed Res. Int. 2014: 408939. doi: 10.1155/2014/408939

Poschl, U. and Shiraiwa, M. (2015). Multiphase chemistry at the atmosphere-biosphere interface influencing climate and public health in the Anthropocene. Chem. Rev. 115: 4440-4475. doi: 10.1021/cr500487s

Qu, C., Li, B., Wu, H., Wang, S. and Giesy, J.P. (2015). Multi-pathway assessment of human health risk posed by polycyclic aromatic hydrocarbons. Environ. Geochem. Health. 37: 587-601. doi: 10.1007/s10653-014-9675-7

Ravindra, K., Sokhi, R. and Van Grieken, R. (2008). Atmospheric polycyclic aromatic hydrocarbons: Source attribution, emission factors and regulation. Atmos. Environ. 42: 2895-2921. doi: 10.1016/j.atmosenv.2007.12. 010

Ray, D., Chatterjee, A., Majumdar, D., Ghosh, S.K. and Raha, S. (2017). Polycyclic aromatic hydrocarbons over a tropical urban and a high altitude Himalayan Station in India: Temporal variation and source apportionment. Atmos. Res. 197: 331-341. doi: 10.1016/j.atmosres. 2017. 07.010

Rengarajan, T., Rajendran, P., Nandakumar, N., Lokeshkumar, B., Rajendran, P. and Nishigaki, I. (2015). Exposure to polycyclic aromatic hydrocarbons with special focus on cancer. Asian Pac. J. Trop. Biomed. 5: 182-189. doi: 10.1016/S2221-1691(15)30003-4

Richter, H. and Howard, J.B. (2000). Formation of polycyclic aromatic hydrocarbons and their growth to soot-A review of chemical reaction pathways. Prog. Energy Combust. 26: 565-608. doi: 10.1016/S03601285(00)00009-5

Saha, M., Maharana, D., Kurumisawa, R., Takada, H., Yeo, B.G., Rodrigues, A.C., Bhattacharya, B., Kumata, H., Okuda, T., He, K., Ma, Y., Nakajima, F., Zakaria, M.P., Giang, D.H. and Viet, P.H. (2017). Seasonal trends of atmospheric PAHs in five Asian megacities and source detection using suitable biomarkers. Aerosol Air Qual. Res. 17: 2247-2262. doi: 10.4209/aaqr.2017.05.0163 
Shen, H., Tao, S., Liu, J., Huang, Y., Chen, H., Li, W., Zhang, Y., Chen, Y., Su, S., Lin, N., Xu, Y., Li, B., Wang, $X$. and Liu, W. (2014). Global lung cancer risk from PAH exposure highly depends on emission sources and individual susceptibility. Sci. Rep. 4: 6561. doi: 10.1038/s rep06561

Shimmo, M., Saarnio, K., Aalto, P., Hartonen, K., Hyötyläinen, T., Kulmala, M. and Riekkola, M.L. (2004). Particle size distribution and gas-particle partition of polycyclic aromatic hydrocarbons in Helsinki urban area. J. Atmos. Chem. 47: 223-241. doi: 10.1023/B:JOCH.0000021088. 37771.f7

Shivani, Gadi, R., Sharma, S.K., Mandal, T.K., Kumar, R., Sharma, M., Kumar, S. and Kumar, S. (2018). Levels and sources of organic compounds in fine ambient aerosols over National Capital Region of India. Environ. Sci. Pollut. Res. 25: 31071-31090.

Shrivastava, A. and Gupta, V. (2011). Methods for the determination of limit of detection and limit of quantitation of the analytical methods. Chron. Young Sci. 2: 21-25. doi: 10.4103/2229-5186.79345

Simayi, M., Yahefu, P. and Han, M. (2018). Spatiotemporal variation, source analysis, and health risk assessment of particle-bound PAHs in Urumqi, China. Aerosol Air Qual. Res. 18: 2728-2740. doi: 10.4209/aaqr.2018.04.0151

Singh, M., Phuleria, H. C., Bowers, K. and Sioutas, C. (2005). Seasonal and spatial trends in particle number concentrations and size distributions at the children's health study sites in Southern California. J. Exposure Sci. Environ. Epidemiol. 16: 3. doi: 10.1038/sj.jea.7500432

Srogi, K. (2007). Monitoring of environmental exposure to polycyclic aromatic hydrocarbons: A review. Environ. Chem. Lett. 5: 169-195. doi: 10.1007/s10311-007-0095-0

Stanier, C.O., Khlystov, A.Y. and Pandis, S.N. (2004). Ambient aerosol size distributions and number concentrations measured during the Pittsburgh Air Quality Study (PAQS). Atmos. Environ. 38: 3275-3284. doi: 10.1016/j.atmosenv.2004.03.020.

Sugiyama, T., Kojiro Shimada, K., Miura, K., Lin, N.H., Kim, Y.P., Chan, C.K., Takami, A. and Hatakeyama, S. (2017). Measurement of ambient PAHs in Kumamoto: Differentiating local and transboundary air pollution. Aerosol Air Qual. Res. 17: 3106-3118.

Taghvaeea, S., Sowlata, M.H., Hassanvand, M.S., Yunesian, M, Naddafi, K, and Sioutas, C. (2018). Source-specific lung cancer risk assessment of ambient $\mathrm{PM}_{2.5}$-bound polycyclic aromatic hydrocarbons (PAHs) in central Tehran. Environ. Int. 120: 321-332. doi: 10.1016/j.envint. 2018.08.003.

Terzi, E. and Samara, C. (2004). Gas-particle partitioning of polycyclic aromatic hydrocarbons in Urban, Adjacent coastal, and continental background sites of western Greece. Environ. Sci. Technol. 38: 4973-4978. doi: 10.1021/es040042d

U.S. EPA (2011). Exposure Factors Handbook 2011 Edition (Final Report). U.S. Environmental Protection Agency, Washington, DC, EPA/600/R-09/052F, 2011.

Vadrevu, K.P., Lasko, K., Giglio, L. and Justice, C. (2015). Vegetation fires, absorbing aerosols and smoke plume characteristics in diverse biomass burning regions of Asia. Environ. Res. Lett. 10: 105003.

Velali, E., Papachristou, E., Pantazaki, A., CholiPapadopoulou, T., Argyrou, N., Tsourouktsoglou, T., Lialiaris, S., Constantinidis, A., Lykidis, D., Lialiaris, T. S., Besis, A., Voutsa, D. and Samara, C. (2016). Cytotoxicity and genotoxicity induced in vitro by solventextractable organic matter of size-segregated urban particulate matter. Environ. Pollut. 218: 1350-1362. doi: 10.1016/j.envpol.2016.09.001

Venkataraman, C. and Friedlander, S.K. (1994). Size distributions of polycyclic aromatic hydrocarbons and elemental carbon. 2. Ambient measurements and effects of atmospheric processes. Environ. Sci. Technol. 28: 563572. doi: 10.1021/es00053a006

Venkataraman, C., Thomas, S. and Kulkarni, P. (1999). Size distributions of polycyclic aromatic hydrocarbonsgas/particle partitioning to urban aerosols. J. Aerosol Sci. 30: 759-770. doi: 10.1016/S0021-8502(98)00761-7

Venkataraman, C., Negi, G., Brata Sardar, S. and Rastogi, R. (2002). Size distributions of polycyclic aromatic hydrocarbons in aerosol emissions from biofuel combustion. J. Aerosol. Sci. 33: 503-518. doi: 10.1016/S0021-8502(0 1)00185-9

Wang, J., Zhang, M., Bai, X., Tan, H., Li, S., Liu, J., Zhang, R., Wolters, M.A., Qin, X., Zhang, M., Lin, H., Li, Y., Li, J. and Chen, L. (2017). Large-scale transport of $\mathrm{PM}_{2.5}$ in the lower troposphere during winter cold surges in China. Sci. Rep. 7: 13238. doi: 10.1038/s41598-017-13217-2

Wang, Y.Q., Zhang, X.Y. and Draxler, R.R. (2009). TrajStat: GIS-based software that uses various trajectory statistical analysis methods to identify potential sources from long-term air pollution measurement data. Environ. Modell. Software 24: 938-939. doi: 10.1016/j.envsoft.200 9.01.004

Wang, Y.Q. (2014). MeteoInfo: GIS software for meteorological data visualization and analysis. Meteorol. Appl. 21: 360-368. doi: 10.1002/met.1345

Winker, D.M., Vaughan, M.A., Omar, A., Hu, Y., Powell, K.A., Liu, Z., Hunt, W.H. and Young, S.A. (2009). Overview of the CALIPSO mission and CALIOP data processing algorithms. J. Atmos. Ocean. Tech. 26: 2310 2323. doi: $10.1175 / 2009$ jtecha 1281.1

Wnorowski, A. (2017). Characterization of the ambient air content of parent polycyclic aromatic hydrocarbons in the Fort McKay region (Canada). Chemosphere 174: 371379. doi: 10.1016/j.chemosphere.2017.01.114

Xu, G., Jiao, L., Zhang, B., Zhao, S., Yuan, M., Gu, Y., Liu, J. and Tang, X. (2017). Spatial and temporal variability of the $\mathrm{PM}_{2.5} / \mathrm{PM}_{10}$ ratio in Wuhan, central China. Aerosol Air Qual. Res. 17: 741-751. doi: 10.4209/aaqr.2016.09.0406

Yang, D., Li, C., Lau, A.K.H. and Li, Y. (2013). Long-term measurement of daytime atmospheric mixing layer height over Hong Kong. J. Geophys. Res. Atmos. 118: 24222433. doi: 10.1002 /jgrd.50251

Yang, T.T., Hsu, C.Y., Chen, Y.C., Young L.H., Huang, C.H. and $\mathrm{Ku}, \mathrm{C} . \mathrm{H}$. (2017). Characteristics, sources, and health risks of atmospheric $\mathrm{PM}_{2.5}$-bound polycyclic aromatic hydrocarbons in Hsinchu, Taiwan. Aerosol Air 
Qual. Res. 17: 563-573. doi: 10.4209/aaqr.2016.06.0283

Yunker, M.B., Macdonald, R.W., Vingarzan, R., Mitchell, R.H., Goyette, D. and Sylvestre, S. (2002). PAHs in the Fraser River basin: A critical appraisal of PAH ratios as indicators of PAH source and composition. Org. Geochem. 33: 489-515. doi: 10.1016/S0146-6380(02)00002-5

Zhang, H., Wang, R., Xue, H., Hu, R. and Liu, G. (2018a). Characteristic and source of atmospheric $\mathrm{PM}_{10^{-}}$and $\mathrm{PM}_{2.5}$-bound PAHs in a typical metallurgic city near Yangtze River in China. Bull. Environ. Contam. Toxicol. 100: 303-309. doi: 10.1007/s00128-017-2217-0

Zhang, N., Cao, J., Li, L., Ho, S.S.H., Wang, Q., Zhu, C. and Wang, L. (2018b). Characteristics and source identification of polycyclic aromatic hydrocarbons and $n$-alkanes in $\mathrm{PM}_{2.5}$ in Xiamen. Aerosol Air Qual. Res. 18: 1673-1683. doi: 10.4209/aaqr.2017.11.0493

Zhang, Y., Chen, J., Yang, H., Li, R. and Yu, Q. (2017). Seasonal variation and potential source regions of $\mathrm{PM}_{2.5^{-}}$ bound PAHs in the megacity Beijing, China: Impact of regional transport. Environ. Pollut. 231: 329-338. doi: 10.1016/j.envpol.2017.08.025

Zhang, Y., Yang, L., Zhang, X., Li, J., Zhao, T., Gao, Y., Jiang, P., Li, Y., Chen, Y. and Wang, W. (2019). Characteristics of $\mathrm{PM}_{2.5}$-bound PAHs at an Urban Site and a Suburban Site in Jinan in North China Plain. Aerosol Air Qual. Res. 19: 871-884. doi: 10.4209/aaqr.2018.09.0353

Zuo, Q., Duan, Y. H., Yang, Y., Wang, X.J. and Tao, S. (2007). Source apportionment of polycyclic aromatic hydrocarbons in surface soil in Tianjin, China. Environ. Pollut. 147: 303-310. doi: 10.1016/j.envpol.2006.05.029 Zhu, Q., Zheng, M., Liu, G., Zhang, X., Dong, S., Gao, L. and Liang, Y. (2017). Particle size distribution and gasparticle partitioning of polychlorinated biphenyls in the atmosphere in Beijing, China. Environ. Sci. Pollut. Res. Int. 24: 1389-1396. doi: 10.1007/s11356-016-7936-y

Received for review, June 21, 2019 Revised, September 5, 2019 Accepted, October 4, 2019 